\title{
General Geology of the
}

Mississippi Embayment

By E. M. CUSHING, E. H. BOSWELL, and R. L. HOSMAN

WATER RESOURCES OF THE MISSISSIPPI EMBAYMENT

GEOLOGICAL SURVEY PROFESSIONAL PAPER 448-B

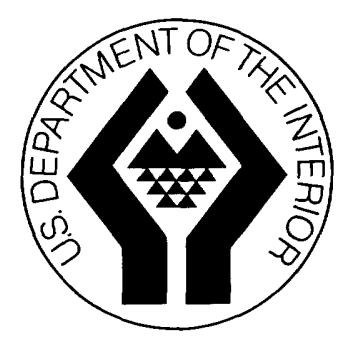

UNITED STATES GOVERNMENT PRINTING OFFICE, WASIIINGTON : 1964 
UNITED STATES DEPARTMENT OF THE INTERIOR

STEWART L. UDALL, Secretary

GEOLOGIGAL SURVEY

William T. Pecora, Director

First printing 1964

Second printing 1968

For sale by the Superintendent of Documents, U.S. Government Printing Office Washington, D.C. 20402 


\section{CONTENTS}

Abstract.-1

Introduction.

Method of study

Acknowledgments.....

Geology

Stratigraphy

Paleozoic rocks.

Cretaceous System._.....

Lower Cretaceous Series..

Trinity Group.

Upper Cretaceous Series.....

Tuscaloosa Group........

Massive sand.....

Coker Formation.

Gordo Formation.

Woodbine Formation.

Eagle Ford Shale.......

MoShan Formation.

Eutaw Formation.

Tokio Formation.

Blossom Sand and Bonham Marl........

Selma Group.

Mooreville Chalk _._.

Coffee Sand........

Demopolis Chalk...................

Ripley Formation.

Prairie Bluff Chalk and Owl Creek Formation.

Demopolis Formation.

Brownstown Marl

Ozan Formation.

Annona Chalk

Marlbrook or Taylor Marl

Navarro Group.......

Saratoga Chalk

Nacatoch Sand...........

Arkadelphia Marl.

Tertiary System.

Paleocene Series

Midway Group._._.

Clayton Formation.

Kincaid Formation.

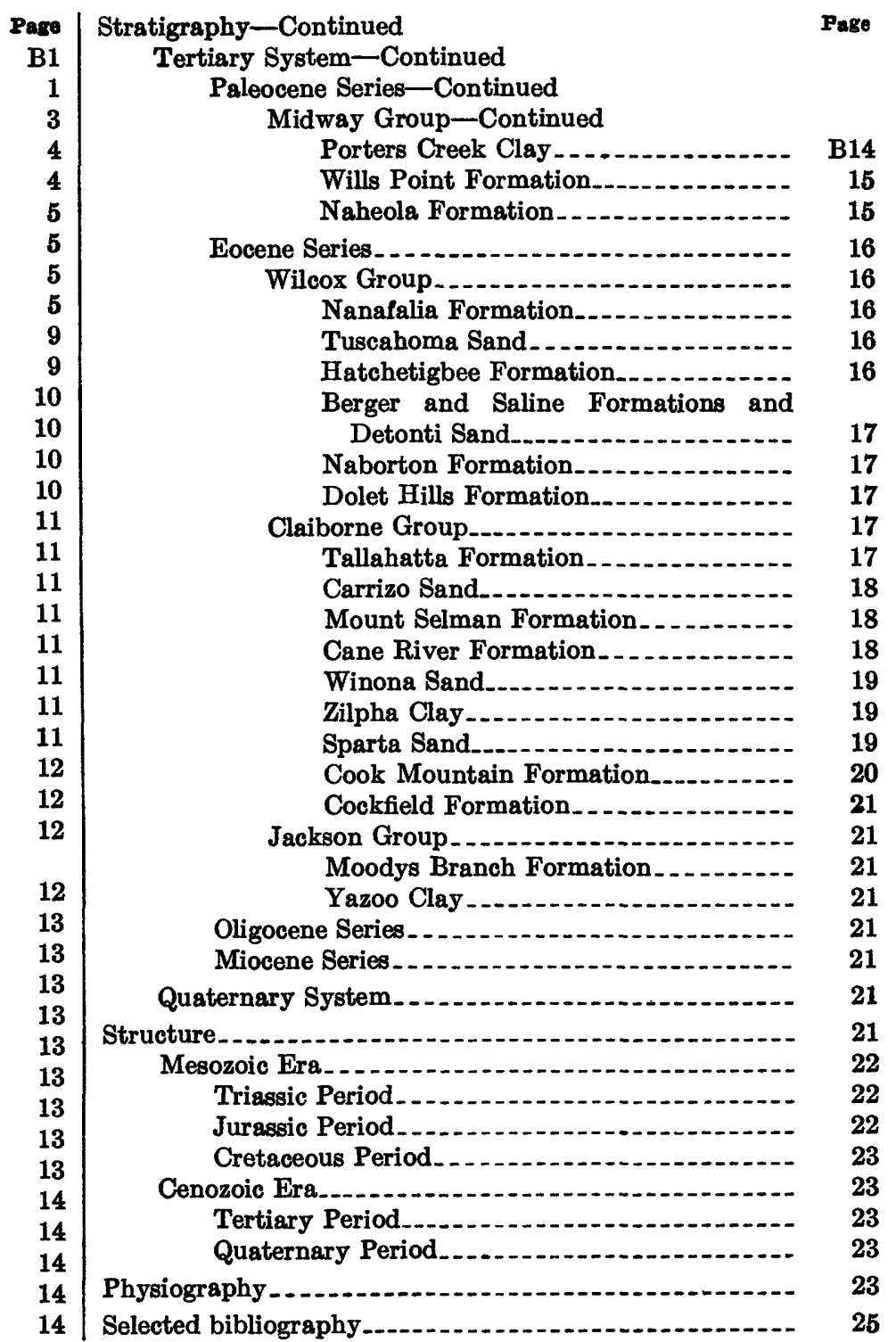

III 


\section{ILLUSTRATIONS}

[Plates are in pocket]

Plate 1. Fence diagram showing geology of Mississippi embayment.

2. Geologic sections of Mississippi embayment.

Page

B2

1. Map showing area of study

3. Mean annual precipitation in the Mississippi embayment.

4-8. Contour maps showing configuration of:

4. Top of the Paleozoic rocks.

5. Top of the Cretaceous System

6. Base of the sandy zone above the Porters Creek Clay.

7. Base of the Cane River Formation or its equivalents.

8. Top of the Sparta Sand.

9. Structure map of the Mississippi embayment

10. Physiographic map of the Mississippi embayment.

\section{TABLES}

TABLE 1. Stratigraphic columns.

2. Oil tests and wells shown on fence diagram and geologic sections. 


\title{
WATER RESOURCES OF THE MISSISSIPPI EMBAYMENT
}

\section{GENERAL GEOLOGY OF THE MISSISSIPPI EMBAYMENT}

\author{
By E. M. Cushing, E. H. Boswell, and R. L. Hosman
}

\begin{abstract}
As the first phase in the study of the water resources of the Mississippi embayment, the regional geologic structure and stratigraphy are defined. The Mississippi embayment comprises about 100,000 square miles in the Gulf Coastal Plain. It is a wedge-shaped region extending from its apex in southern Illinois southward to about the 32d parallel and includes parts of Alabama, Arkansas, Illinois, Kentucky, Louisiana, Mississippi, Missouri, Tennessee, and Texas.
\end{abstract}

Most of the major geologic units include water-bearing strata that form vast aquifers, many of which cross State boundaries and are of regional importance. The deep-lying Jurassic rocks are not known to contain potable water, but the Cretaceous, Tertiary, and Quaternary deposits include numerous aquifers, most of which contain fresh water at shallow to moderate depths.

Geologically, the Mississippi embayment is a syncline which plunges to the south and whose axis generally parallels the Mississippi River. The syncline is filled with sedimentary rocks ranging in age from Jurassic to Quaternary and reaching a maximum thickness of about 18,000 feet in the southern part of the region. The lithology and continuity of the geologic units are variable because of modifying structural features and because of the differing depositional environments during the geologic evolution of the region. On the basis of interpretations of electric logs and some drillers' logs, contour maps were prepared showing configuration of the top of the Paleozoic rocks, the top of the Cretaceous System, the base of the sandy zone above the Porters Creek Clay, the base of the Cane River Formation or its equivalents, and the top of the Sparta Sand. A fence diagram and four sections show the stratigraphic relation of the major geologic units, and for areas near the outcrops of these units the sections are more detailed.

Important structural features in the embayment are the Sabine and Monroe uplifts, the Jackson dome, the East Texas and Desha basins, and the Arkansas and Pickens-Gilbertown fault zones. These structures, all of post-Paleozoic age, were formed, in part, contemporaneously with the sedimentation of the embayment and have had considerable influence on the depositional environment of the region.

\section{INTRODUCTION}

For several years the need for an appraisal of the water resources of the Mississippi embayment has been recognized by people associated with the development of the region. Most of the water-resources investigations in the embayment have been made in cooperation with State, county, and municipal agencies and have been restricted to local areas where the need for infor- mation was most urgent. Reports on these studies give valuable information on parts of the embayment, but they do not treat the subject of water resources on a regional basis.

The present study, begun in August 1957, is a part of the Federal program of the U.S. Geological Survey. The study is being made to provide an overall picture of the water resources so that these resources can be developed thoroughly and managed efficiently. This report is one of a series that will describe the results of the successive phases of the study.

Proper development, use, and conservation of the water resources can be achieved only through an understanding of the regional geologic environment and its influence on the response of the hydrologic system to climate and to water-supply development. Within the limits of time, personnel, and data available, the objectives of the study are aimed toward: (a) defining the regional geologic structure and stratigraphy and determining their influence on the movement, availability, and quality of the ground water; (b) determining areas of ground-water recharge and discharge, the directions and rates of flow between these areas, the influence of these areas on the low-flow characteristics of the streams, and the influence of artificial withdrawals on the groundwater reservoirs; (c) determining the relation between the geology and the low-flow characteristics of streams, the expected low flows of streams on a frequency basis, and the storage requirements for maintaining certain minimum flows; (d) studying the relation between streams and ground-water reservoirs; (e) relating, by study of chemical analyses, the chemical quality of the water to its geographic and geologic environment; and (f) determining the downdip extent of fresh water in the formations and the presence of chloride, fluoride, nitrate, and other chemical constituents which in excess concentrations could possibly restrict the usefulness of the water.

The Mississippi embayment, as defined in this report, comprises about 100,000 square miles in the Gulf Coastal Plain. From its apex in southern Illinois, the 
embayment fans out southward to about the $32 \mathrm{~d}$ parallel and includes parts of Alabama, Arkansas, Illinois, Kentucky, Louisiana, Mississippi, Missouri, Tennessee, and Texas. (See fig. 1.) Some of the larger cities within the region are: Tuscaloosa, Ala.; Jackson, Miss.; Monroe and Shreveport, La.; Texarkana, Ark.-Tex.; Little Rock, Ark.; and Memphis, Tenn.

For some millions of years this region was an embayment periodically occupied by an arm of the sea in which as much as several thousand feet of sediments were deposited. Deposits of sand now form vast regional aquifers (water-bearing units), some of which are known to produce large quantities of water. These aquifers extend across State and topographic boundaries and underlie various watersheds.

The embayment is drained by several large streams, most of which belong to the Mississippi River system. An area in the southeastern part of the region is drained by tributaries of streams which flow separately into the Gulf of Mexico.

The region has a moderate climate. The mean annual temperature ranges from about $58^{\circ} \mathrm{F}$ in the northern part of the region to $66^{\circ} \mathrm{F}$ in the southern part (fig. 2), and the mean annual precipitation ranges

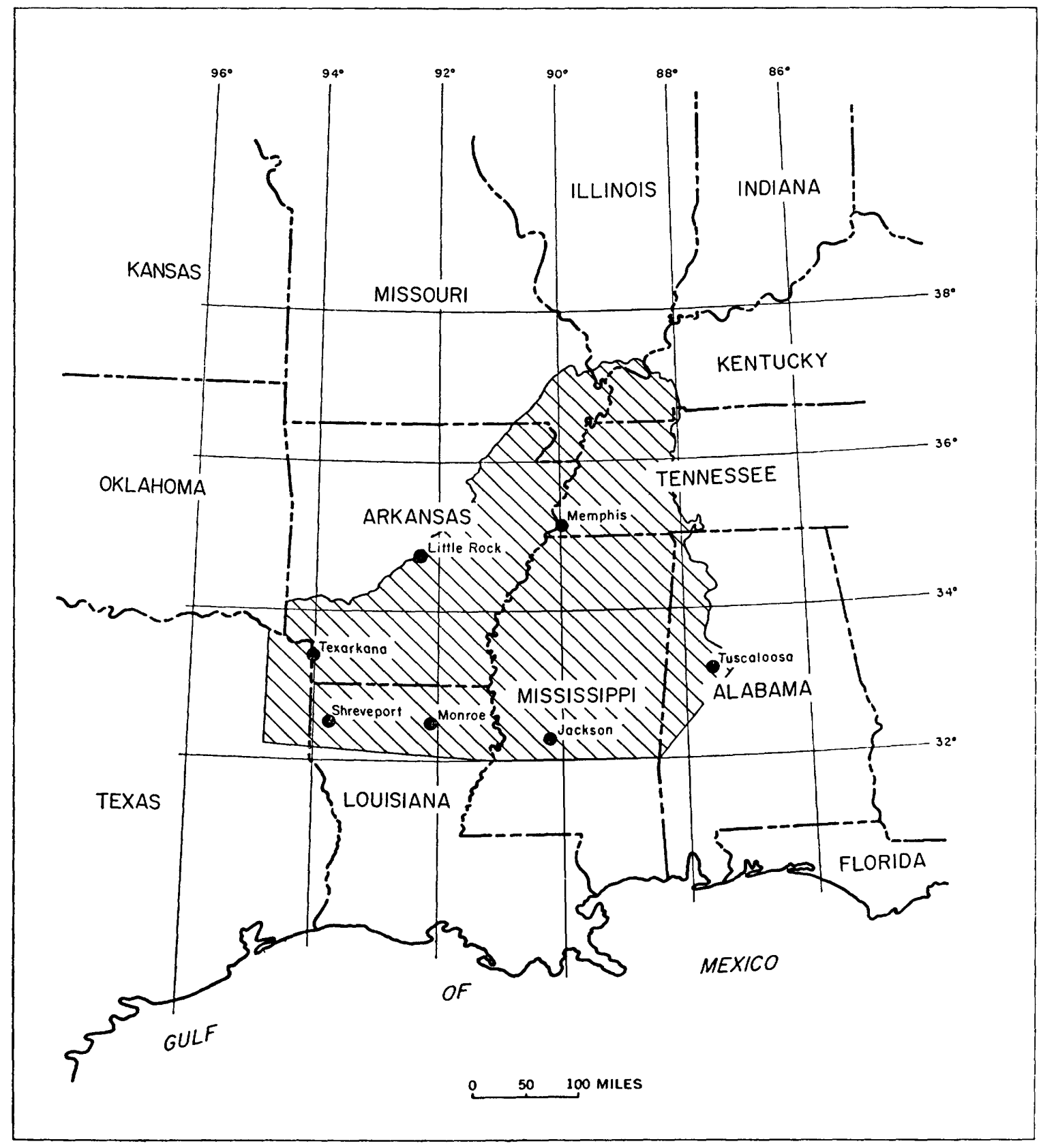

Froure 1.-Map showing area of study. 


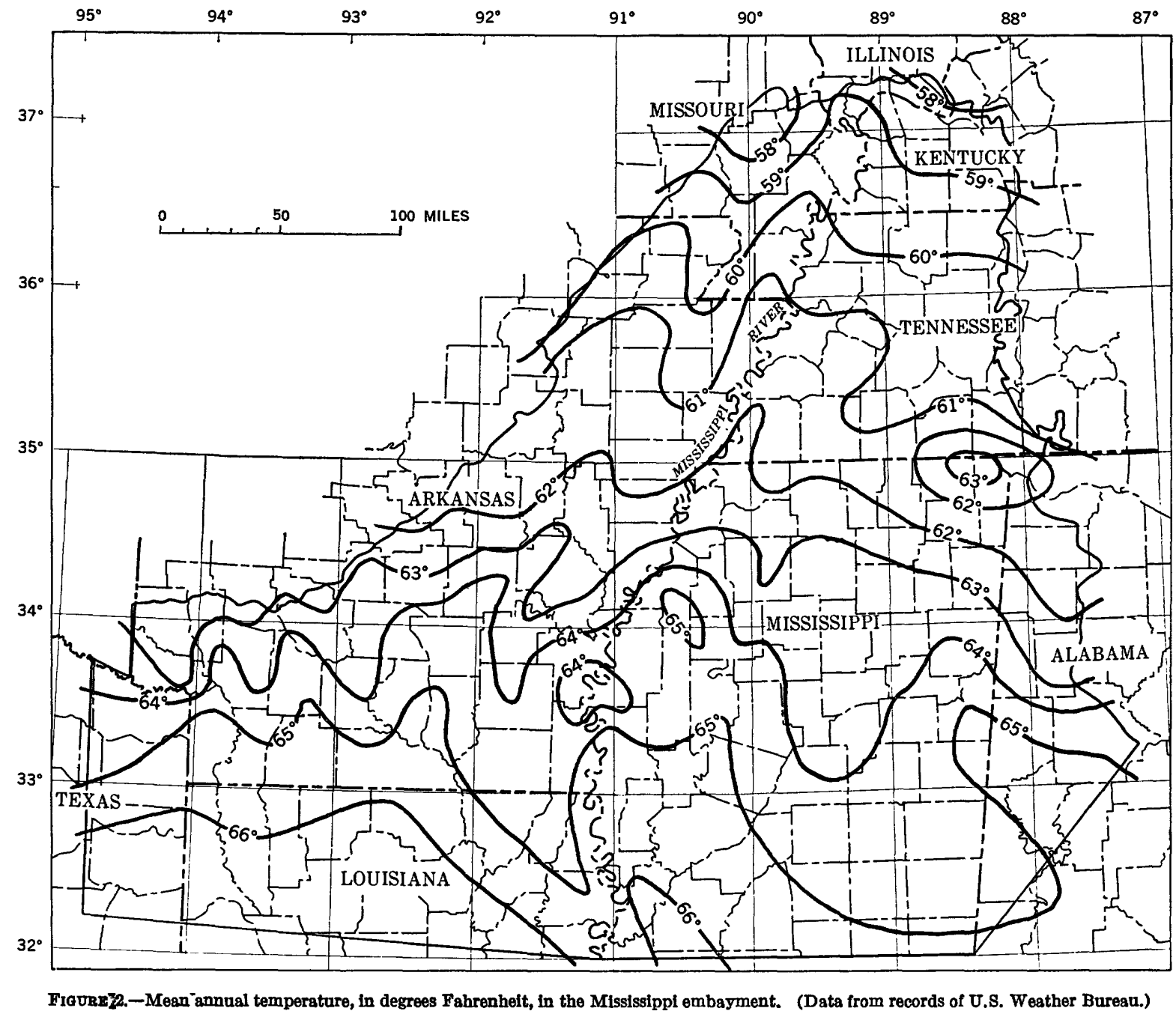

generally from 48 inches in the northern part to 56 inches in the southern part (fig. 3). Although the annual precipitation is high, most of it occurs during the winter and spring; droughts are common during the summer and fall.

The economy of the region is basically agricultural, but industry has become increasingly important since World War II. The diversification and mechanization of agriculture have resulted in a surplus of manpower, most of which is being absorbed by the expansion of industry. The population, although still predominantly rural, is becoming urban. Further industrial expansion probably will occur because of available manpower, natural resources, and economical transportation. Increasing demands on available water supplies will be made, and the future economy of the embayment is largely dependent upon intelligent utilization and management of the region's water resources.

One of the first phases of an areal water-resources study is to define the generalized structure and stratigraphy so that more detailed subsurface studies and the correlation of the water-bearing units can be made. This report summarizes the general geology of the region.

\section{METHOD OF STUDY}

Description of the generalized regional structure and stratigraphy is based primarily on the interpretation of the available electric logs of wells and oil test holes. In areas where electric logs are not available, attempts were made to use available drillers' logs; generally, however, these logs were not detailed enough for accurate correlation with the electric logs. Most of the geologic interpretation is based on previously established and generally recognized unit boundaries. Some microscopic and micropaleontologic examinations of well cuttings were made to verify the interpretation of the electric and drillers' logs.

On the basis of the interpretations, a fence diagram showing the geology of the region, a structure map, four regional geologic sections, and five contour maps were prepared. 


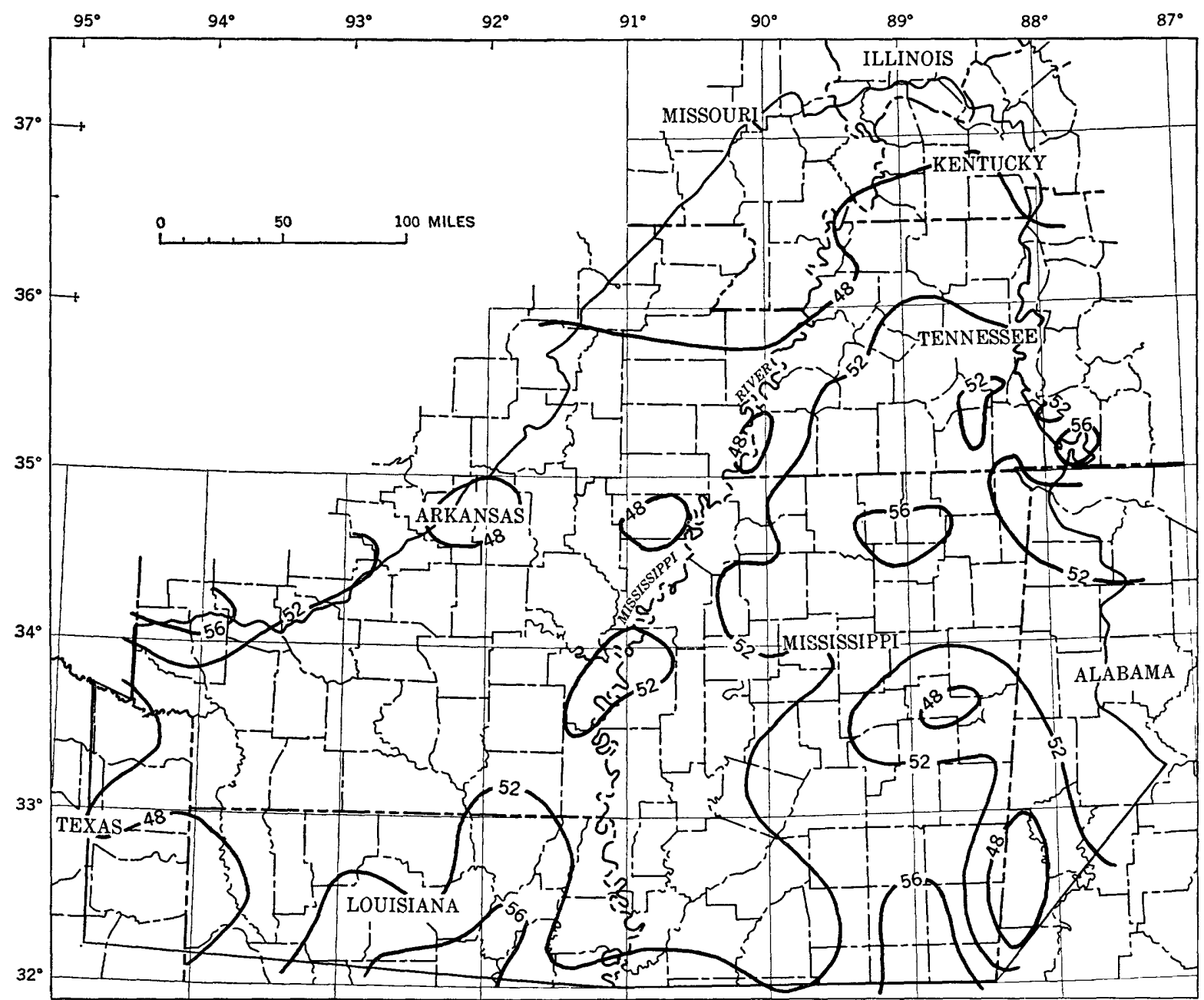

Figure 3.-Mean annual precipitation, in inches, in the Mississippi embayment. (Compiled from maps of U.S. Weather Bureau and records of Tennessee Valley Authority.)

Work on the ground-water phases of the study is under the direction of E. M. Cushing. Fieldwork and data synthesis and analysis to date (1960) were done by J. G. Newton for Alabama, R. L. Hosman for Arkansas, L. M. MacCary and T. W. Lambert for Kentucky, W. H. Walker and C. E. Harris, Jr., for Louisiana, E. H. Boswell for Mississippi, G. K. Moore and J. H. Criner, Jr., for Tennessee, and E. T. Baker, Jr., and William Ogilbee for Texas. Lithologic and micropaleontologic studies are being made by S. M. Herrick. Work on the surface-water phases is under the direction of P. R. Speer, and that on the quality-ofwater phases is under the direction of M. E. Schroeder.

\section{ACKNOWLEDGMENTS}

The suggestions, assistance, and cooperation of the following State officials and members of their staffs are gratefully appreciated: Walter B. Jones, State Geologist, Geological Survey of Alabama; Norman F. Williams, Geologist-Director, Arkansas Geological and
Conservation Commission; John C. Frye, Chief, Illinois Geological Survey; Wallace W. Hagan, Director and State Geologist, Kentucky Geological Survey; Arthur C. McFarlan, Head of Geology Department, University of Kentucky; Leo W. Hough, State Geologist, Louisiana Geological Survey; Tracy W. Lusk, Director and State Geologist, Mississippi Geological Survey; Thomas R. Beveridge, Director and State Geologist, Missouri Geological Survey; William D. Hardeman, State Geologist, Tennessee Division of Geology; and the late John T. Lonsdale, former Director, Texas Bureau of Economic Geology. These officials also furnished or made available geologic information and many electric logs and sets of well cuttings for this study. Shell Oil Co., Jackson, Miss., allowed the authors access to the well cuttings in its repository.

\section{GEOLOGY}

Within the Mississippi embayment, sediments ranging in age from Jurassic to Quaternary have been 
deposited and have a maximum thickness of about 18,000 feet in the southern part of the region. Units ranging in age from Cretaceous to Quaternary crop out within the area of study (pl. 1). These units of gravel, sand, silt, clay, lignite, marl, chalk, and limestone range in thickness from zero at the outcrop of Paleozoic rocks to several thousand feet at the axis of the embayment structural trough.

This report is concerned primarily with the stratigraphic relationship and areal extent of the units of Late Cretaceous age and younger, and with the general correlation of the units within the embayment. Table 1 shows the stratigraphic columns used by the U.S. Geological Survey (May 10, 1961) for the Upper Cretaceous, Paleocene, Eocene, and Oligocene units in the area of study.

\section{STRATIGRAPHY}

Available electric logs of wells and oil tests in the embayment were used to define the generalized regional stratigraphy. The geologic interpretations of the logs are based primarily on established and generally recognized unit boundaries. Some microscopic and micropaleontologic examinations of well cuttings were made to verify these boundaries.

The geologic contacts shown on a regional fence diagram (pl. 1) include the top of the Paleozoic rocks, the top of the Lower Cretaceous Series, the top of the Upper Cretaceous Series, the base of the sandy zone immediately above the Porters Creek Clay, the top of the Wilcox, the top of the Claiborne Group, and the top of the Jackson Group. The Oligocene and Miocene Series are shown as a unit, as is the Quaternary System.

Plate 2 is a group of regional geologic sections. These sections show the correlation of the groups or larger units in the embayment and the stratigraphic position of most of the formational units near their areas of outcrop. In the extreme northern part of the embayment, Eocene deposits have not been subdivided. Facies changes in the units in this interval and the lack of subsurface information have prevented the tracing of the recognized unit boundaries from the southern part of the region into the northern part. Fossils, which would be useful in the attempt to subdivide these Eocene units, apparently do not exist in the northern part of the embayment.

Wells shown on the fence diagram and on the sections are listed in table 2. The well numbers are those used in each State by the district office of the Branch of Ground Water of the U.S. Geological Survey.

\section{PALEOZOIC ROCKS}

Although igneous intrusive rocks occur in some places, the basement rocks that form the synclinal structure of the Mississippi embayment are mostly of
Paleozoic age, ranging from Cambrian to Pennsylvanian. Although irregular, the slope of the Paleozoic surface is generally toward the axis of the embayment in the northern part of the region and changes gradually toward the Gulf of Mexico on the southern flanks. Figure 4 is a contour map showing configuration of the top of the Paleozoic rocks.

Within the embayment, near its periphery, water in rocks of Paleozoic age is utilized.

\section{CRETACEOUS SYSTEM}

Deposits of Cretaceous age rest unconformably on rocks of Paleozoic age throughout the embayment except in the extreme southern part, where Lower Cretaceous deposits overlie truncated Jurassic strata. The Cretaceous sediments are mostly of marine origin and are largely calcareous, ranging from sands to clays, chalks, and marls. Some reef-type limestones are present locally.

The dip of Cretaceous strata is generally toward the axis of the embayment except in the southern part of the region, where the dip gradually swings southward toward the Gulf of Mexico. Structural features within the embayment affect the dip of Cretaceous strata locally.

Figure 5 is a contour map showing the configuration of the top of the Cretaceous System.

\section{LOWER CRETACEOUS SERTES}

The 34th parallel marks the approximate northernmost limit of Early Cretaceous deposition in the Mississippi embayment. Post-Early Cretaceous erosion during the rise of the Monroe uplift completely removed the Lower Cretaceous rocks in southeastern Arkansas and part of northeastern Louisiana; Lower Cretaceous beds are truncated around the southern flank of the uplift.

Lower Cretaceous rocks do not crop out on the eastern side of the embayment. However, in Mississippi and Alabama they occur in the subsurface as thick sands, clays, and shales. Lower Cretaceous beds crop out in a westward-trending band in southwestern Arkansas and southeastern Oklahoma, and extend downdip into Louisiana and Texas. These beds have been designated the Trinity Group, which comprises several formations.

Southwestern Arkansas is the only area in the Mississippi embayment where fresh ground water is obtained from wells drilled into these rocks. Analysis of electric logs indicates that the Lower Cretaceous deposits may contain fresh water in a small area in east-central Mississippi and western Alabama but that elsewhere in Mississippi and in Alabama the water is probably too mineralized for most uses. 


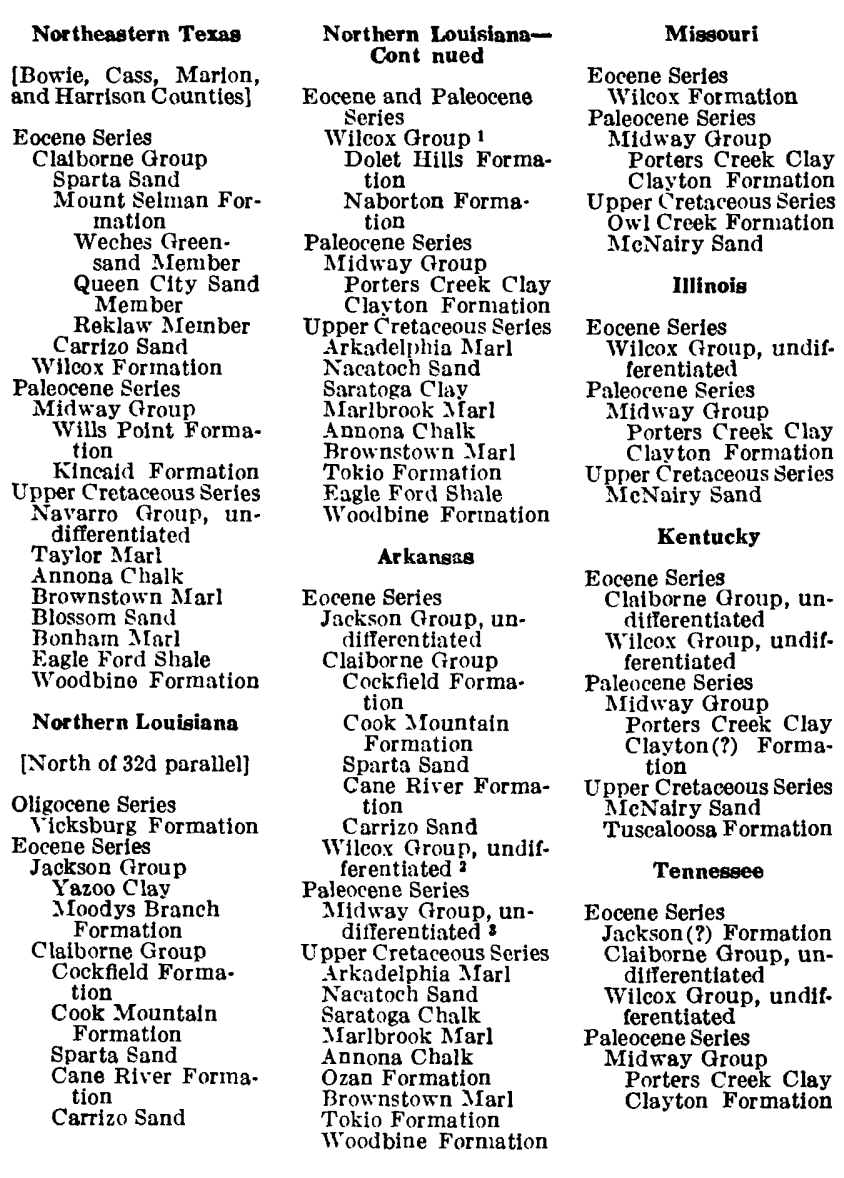

TABLE 1.-Stratigraphic columns

\begin{tabular}{|c|c|}
\hline & \\
\hline Tennessee - Continued & Northern Mississippi \\
\hline $\begin{array}{l}\text { Upper Cretaceous Series } \\
\text { Owl Creek Formuntion }\end{array}$ & [Southern part] \\
\hline $\begin{array}{l}\text { Ripley Formation } \\
\text { MeNairy sand } \\
\text { TSamber }\end{array}$ & $\begin{array}{l}\text { Eocene Series } \\
\text { Jackson Group, undif }\end{array}$ \\
\hline $\begin{array}{l}\text { Member } \\
\text { Coon Creek Tongue }\end{array}$ & $\begin{array}{l}\text { ferentiated } \\
\text { Claiborne Group }\end{array}$ \\
\hline $\begin{array}{l}\text { Demopolis Formation } \\
\text { Coffee Sand }\end{array}$ & $\begin{array}{l}\text { Cock field Forina- } \\
\text { titn }\end{array}$ \\
\hline $\begin{array}{l}\text { Eutaw Formation } \\
\text { Tuscaloosa Formation }\end{array}$ & Cook Mountain \\
\hline & $\begin{array}{l}\text { Fornation } \\
\text { Sparta Sand }\end{array}$ \\
\hline Northern Mississippi & Zipha Clay \\
\hline [Northern part] & $\begin{array}{l}\text { Winona Sand } \\
\text { Tallahatta Forma- }\end{array}$ \\
\hline $\begin{array}{l}\text { Eocene Series } \\
\text { Jackson Group, undif- }\end{array}$ & $\begin{array}{l}\text { Wilcox Formation } \\
\text { Paleocene Series }\end{array}$ \\
\hline $\begin{array}{l}\text { ferentiated } \\
\text { Claiborne Group }\end{array}$ & $\begin{array}{l}\text { Midway Group } \\
\text { Naheola Formation }\end{array}$ \\
\hline Cockfield Forma- & Porters Creek Clay \\
\hline $\begin{array}{l}\text { tion } \\
\text { Cook Mountain }\end{array}$ & $\begin{array}{l}\text { Clayton Formation } \\
\text { Upper Cretaceous Series }\end{array}$ \\
\hline $\begin{array}{l}\text { Fornation } \\
\text { Sparta Sand }\end{array}$ & Selma Group \\
\hline $\begin{array}{l}\text { Zilpha Clay } \\
\text { Wilnona sand }\end{array}$ & $\begin{array}{l}\text { Prairie Bluff Chalk } \\
\text { Ripley Formation }\end{array}$ \\
\hline $\begin{array}{l}\text { Winona Sand } \\
\text { Tallahatta Forma- } \\
\text { tion }\end{array}$ & $\begin{array}{l}\text { Demopolis Chalk } \\
\text { Bluftport Marl }\end{array}$ \\
\hline 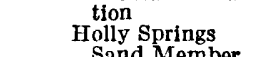 & $\begin{array}{l}\text { Member } \\
\text { ooreville Chalk }\end{array}$ \\
\hline $\begin{array}{l}\text { Sand Member } \\
\text { Wilcox Formation }\end{array}$ & Arcola Limestone \\
\hline $\begin{array}{l}\text { Paleocene Series } \\
\text { Midway Group }\end{array}$ & $\begin{array}{l}\text { Eutaw Formation } \\
\text { Eormat }\end{array}$ \\
\hline $\begin{array}{l}\text { Midway Group } \\
\text { Porters Creek Clay } \\
\text { Tippah Sand Len. }\end{array}$ & Tombigbee Sand \\
\hline Tippah Sand Len. & $\begin{array}{l}\text { Member } \\
\text { McShan Formation }\end{array}$ \\
\hline $\begin{array}{c}\text { til } \\
\text { Clayton Formation } \\
\text { Upper Cretaceous Series }\end{array}$ & $\begin{array}{l}\text { uscaloosa Group, } \\
\text { undifferentiated }\end{array}$ \\
\hline $\begin{array}{l}\text { Upper Cretaceous Series } \\
\text { Selma Group }\end{array}$ & \\
\hline $\begin{array}{l}\text { Owl Creek Forma- } \\
\text { tion }\end{array}$ & \\
\hline $\begin{array}{l}\text { Ripley Formation } \\
\text { Chiwapa Member }\end{array}$ & \\
\hline $\begin{array}{l}\text { McNairy Sand } \\
\text { Member }\end{array}$ & \\
\hline $\begin{array}{l}\text { Member } \\
\text { Cook Creek }\end{array}$ & \\
\hline $\begin{array}{l}\text { Tongue } \\
\text { Transitional clay }\end{array}$ & \\
\hline $\begin{array}{l}\text { Demopolis Chalk } \\
\text { Coffee Sand }\end{array}$ & \\
\hline $\begin{array}{l}\text { Coftee Sand } \\
\text { Eutaw Formatfon } \\
\text { Tambigbee Sand }\end{array}$ & \\
\hline $\begin{array}{l}\text { Tombigbee Sand } \\
\text { Member }\end{array}$ & \\
\hline $\begin{array}{l}\text { McShan Formation } \\
\text { Tuscaloosa Group, } \\
\text { undifferentiated }\end{array}$ & \\
\hline
\end{tabular}
Central Mississippi
Oligocene Serles Forest Hill Sand and
Red Bluff Clay Eocene Serles Yazoo Clay Shubuta Membe
Pachuta Marl Member
Cocoa Sand Mem ber North Cree Moodys Branch Formation Claiborne Group tion Cook Mountain Formation
Gordon Creek Shale Member
Potterchitto Sand Potterchitto Sand
Member
Archusa Marl Member Sparta Sand Tallahatta Forma- tion
Neshoba Sand Member
Basic City Sh Meridian Sand Member
Wilcox Formation Wilcox Formation
Bashi Marl Member Fearn Springs
Member

Central Mississippl-
Continued

Paleocene Serles
Midway Group

Naheola Formatio
Cor

Porters Creek Clay

Matthews Land-
ing Marl Mem-

ayton Formatio

Clayton Formation
Upper Cretaceous Series

Prairie Bluff Chalk Ripley Formation Demopolis Chalk
Bluffport Marl

Mooreville Chalk Arcola Limeston untaw Formation MeShan Formation Tuscaloosa Group Coker Formation

Western Alabama

Eocene Serles

Tallahatta Formation
Meridian Sand Wilcox Group

Hatchetigbee Formatton
Basht Marl Mem ber

Tuscahoma Sand
Bells Landing Marl Member
Greggs Landing Mreggs Landing
Marl Member
Nanafalia F ormaNanafalia Forma-
tion Grampian Hills Member
Middle member Travel Creek
Sand Member
Western Alabama-

Midway Group Naheola Formation
Coal Bluff Marl Member
Oak Hill Member mation mation
Matthews Landing Marl MemClayton Formatio
McBryde Limestone Memb
Pine Barren Member
Cretaceous Series Upper Cretaceous Series Prairie Bluff Chalk Ripley Formation Bluffport Marl
Buts Mooreville Chalk
Arcola Limestone
Member Eutaw Formation Member Mcshan Formation Gordo Formatio Coker Formation member
Eoline Member
Massive sand Mossive Mand

1W Wcox Group (Eocene Series), undifferen tiated. Wilcox Group (Paleocene Series), upper part undifferentiated; Dolet Hills and Naborton Formations lower two units.

in ascending order, Wilcox Group Arkansas in bauxite area comprises Berger Formation, Saline Formation, and Detont Sand. 
TABLE 2.-Oil tests and wells shown on fence diagram and geologic sections

\begin{tabular}{|c|c|c|c|}
\hline $\begin{array}{c}\text { County or } \\
\text { parish }\end{array}$ & Well & Company or driller & Well name \\
\hline \multicolumn{4}{|c|}{ Alabama } \\
\hline $\begin{array}{l}\text { Marengo...... } \\
\text { Sumter....... } \\
\text { Tuscaloosa... }\end{array}$ & $\begin{array}{l}\mathrm{I}-31 \\
\mathrm{~S}-23 \\
\mathrm{FF}-35\end{array}$ & $\begin{array}{l}\text { W. A. Moncrief } \\
\text { Blair Oil \& Gas Co Co... } \\
\text { Causey Drilling Co }\end{array}$ & $\begin{array}{l}\text { R. H. Bradford 1. } \\
\text { Allison Lumber Co. } 1 . \\
\text { U.s. Geol. Survey test }\end{array}$ \\
\hline Do....... & ss-24... & ....do............ & \\
\hline
\end{tabular}

\section{Arkaneas}

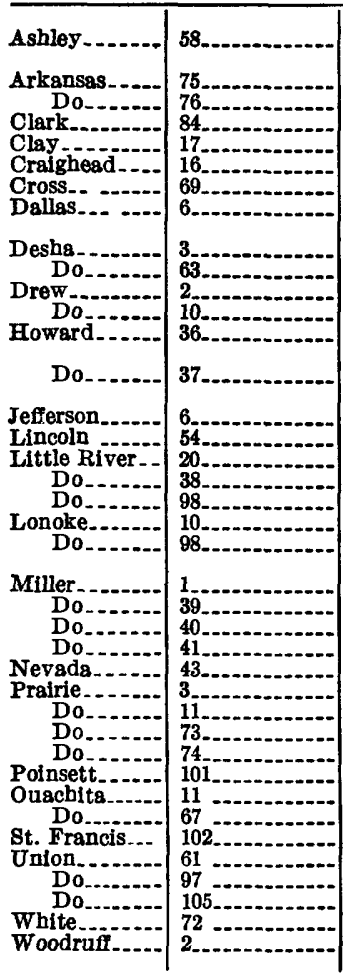

Garland Anthony (J. L. $/$ Crossett Lumber Co.1. Seaboard Oil Co Blackwell Oil \& Gas Co..-. E. P. Fox 1. G. F. Stone-1intin Driling Co Tallatin Drilling Co-.-- J. Callaway 1. Ramsey Petroleum Co... Carter Oil Co. Hunt Oil Coames W. Fair Union Producing Co...-. Simmons et al). ing $\mathrm{Co}$. Gregg Oil CoCurtis Kinard .........-. H. A. Taylor 1. Burnett Producing Co..... Archie Hale A-1.

Lee \& Burnett........... Troth A-1. Burns Ofl $\mathrm{CO}$ Frank F. Silver

Barnsdale Oil Co. Deep Rock Oil $\mathrm{C}_{0 . . . .}$ Don Fitzwater J. H. Coker O11 Corp.... Victory Development Co.. Victory Development Co.do Peters Drining Co Garland Anthon G. H. Vaughn-..Atlontle Lion O11 Co. C. H. Murphy tates O1l Co Singer 1. Lumber Co.-Horne 1. Isom 1 . Thornton 1. Cavaness 1 . Crossett $\mathrm{H}-1$. Rooks 3.

Barton 1.

S. A. Hoots 1.

Joseph Chambers Estate 1.

Nichols 1.

Montana Realty 1

Sherman 1.

M. W. Jones 1.

Sparks Estate 1.

Clayton 1.

Weons Farms 1.

Haltom 1.

Mary 1 . Davis 1.

Gregory 1.
V.T. La Ferney 1. Sol Nathan 1

Kentucky

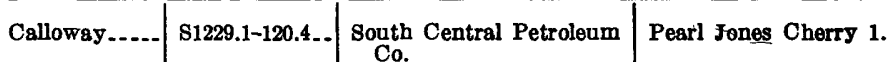

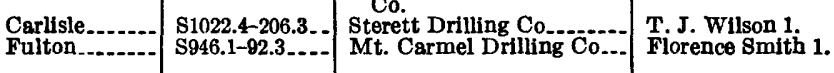

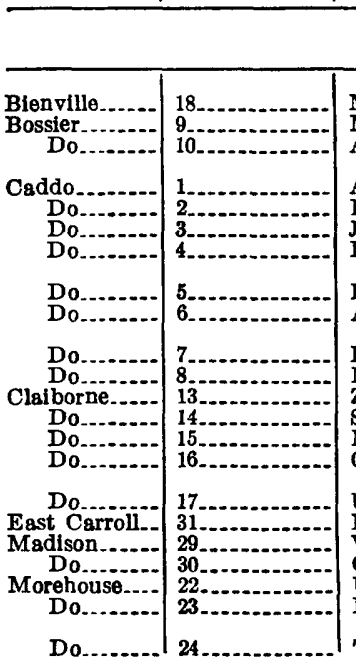

Louisiana

Monsanto Chemical Co ... Ozley 1

$\begin{array}{lll}\text { Monsanto Chemical Co ... } & \text { Ozley 1. } \\ \text { McCalmau Drilling Co... } & \text { S. H. Bollinger Co. } 1 .\end{array}$ A. J. Hodges Industries, Inc.

Arkla onl Co.

K. T. Anderson W. Falr - Browning Royal, $\mathbf{j}$

Phillins Petroleum Co Arkansas-Louisiana Gas

LaGioria Oll \& Gas Corp Max Toblas - ${ }_{2}$ a Zach Brooks Drilling Co Stanolind O1l \& Gas CoCrow Drilling \& Producing $\mathrm{Co}$

Union Producing Co.... Roeser \& Pendleton ........ . S. Parhann.

Soudhelmer 1 .

nion Produeing $\mathrm{CO}_{-}-\mathrm{C}_{\text {Crossett }} \mathrm{C}-1$.

Varndall Oll Co. \& C. N. Crossett 1.

Valerious.
The Texas Co.

w. W. Doles 1.

Skannal C-3.

Mattie Pitts 3.

Moneyham 1.

Bell A-1.

W. C. Agurs 2.

Planters Bank Unit 1 R. F. Odom 1.

Inemphill 1 .

Coleman A-1.

Logan

athan-Johnson 1.
Jerry Screeton 1.

Loftin 1.

\begin{tabular}{|c|c|c|c|}
\hline$\underset{\text { parish }}{\text { County ar }}$ & Well & Company or driller & Well name \\
\hline \multicolumn{4}{|c|}{ Loulsiana-Continued } \\
\hline $\begin{array}{l}\text { Morebouse-... } \\
\text { Do } \\
\text { Ouachita....... } \\
\text { Richland }\end{array}$ & $\begin{array}{l}25 \\
26 \\
21 \\
27\end{array}$ & $\begin{array}{l}\text { Justiss-Mears Oil Co- } \\
\text { Taylor-Kirby Drilling Co- } \\
\text { The California Co } \\
\text { Atlantic Refining Co....... }\end{array}$ & $\begin{array}{l}\text { Evans } 2 . \\
\text { E.M. Clark 1. } \\
\text { Walter Maxey 1. } \\
\text { Mrs. Birdie } 8 \text {. Frank- }\end{array}$ \\
\hline $\begin{array}{l}\text { Union } \\
\text { Do.......... } \\
\text { Webster...... } \\
\text { Do } \\
\text { West Carroli-: }\end{array}$ & $\begin{array}{l}19 \\
11 \\
12 \\
28\end{array}$ & $\begin{array}{l}\text { H. J. Heartwell } \\
\text { Barnwell Drilling Co.... } \\
\text { L. L. Robinson et al. } \\
\text { Hunt Oil Co..... } \\
\text { Pure Oil Co }\end{array}$ & $\begin{array}{l}\text { Griffin } 1 . \\
\text { Facker 1. } \\
\text { Kulpatrick } 1 . \\
\text { Jacinta Sales } 1 . \\
\text { Costello 1. }\end{array}$ \\
\hline
\end{tabular}

\begin{tabular}{|c|c|}
\hline At & 6. \\
\hline $\begin{array}{l}\text { Do } \\
\text { liva }\end{array}$ & 13 \\
\hline Do- & \\
\hline $\begin{array}{l}\text { houn. } \\
\text { Do. }\end{array}$ & 5 \\
\hline Chickase & 2 \\
\hline $\begin{array}{l}\text { Choctaw } \\
\text { Clay _... }\end{array}$ & 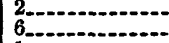 \\
\hline $\begin{array}{l}\text { DeSoto- } \\
\text { Grenada }\end{array}$ & 1 \\
\hline $\begin{array}{r}\text { Do... } \\
\text { Hinds.. }\end{array}$ & 12 \\
\hline & \\
\hline
\end{tabular}

\section{Shell Oil Co}

Dudley $\mathrm{s}$. Weaver et al. Central O Il Co

Hunt Oll $\mathrm{Co}-$

Seaboard Oil Co

Stnclair Oil Co

Henson \& $\mathrm{Bif}$ C Co

Atlantic Refining Co-...

B. H. Williams \& $\mathrm{H}$. $\mathrm{H}$.

Wred Melle.

Love Petroleum čo........

Kingwood Oll Co. \&

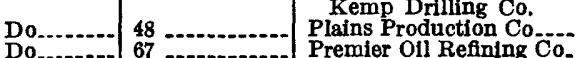

Do........- 69

Do........ $1206 . . . .$.

Holmes.

1231

Leonard Jones

Love Petroleum $\mathrm{Co}$

J. E. Treadway \& D. C

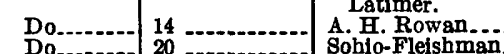

Do

Issaquena....-.

Itawamba....-

Marshall R. Young et ai

Ray Northern \& A. W

Gordon C. Grasty...

Lauderdale... 14............. Rogers Lacy

Leake...............

Lee.

Harold $\mathrm{K}$ Boyse...........

J. F. Michael

Leflore..........

Do........

Do.......

Monroe.-.

Neshoba

Newton-

Noxubee

Prentiss

Levy Board 1.

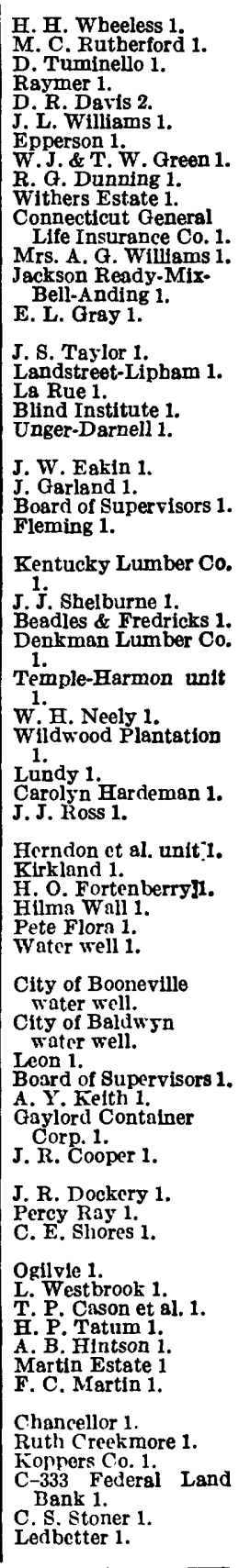
M. Rutberford

J.L. Willis 2.

W.J.\& $\mathbf{T}, \dot{W}$. Green 1

R. . Dunning 1.

Lnecticut General

Mrs. A. G. Williams 1 .

s. Taylor

Landstreet-Lipham 1
R. A. Elliso

Exchange Oil Co...............

Lynn Oil Co

Continental Oil Co

Ray, Shortridge \& Wilso

Drilling Co.

shell

H.

Sun Dil Co ON Co.......

Sun Oil Co--.-

Tennessee Gas Transinis-

sion Co.
Carloss Well Supply Co.

Do.........

Rankin.......

Layne-Central Co........

Monsanto Chemical $\mathrm{Co}_{-}$ IIonolulu Oil Corp

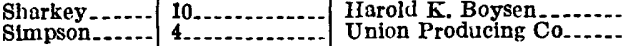

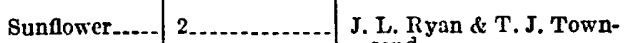

Latex-Gulf Oil Co

Do........

Ohino Oil Co ............

$\mathrm{C}$

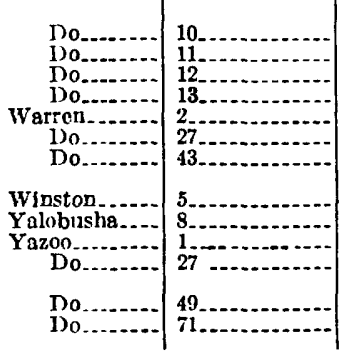

Marshall R. Young.

Lew is \& La Rue-

Marshall R. Young.

Texas Co

Pragnila Petrolcum co

Frontier onl Refnning

Garson \& Grober

Steward Oil Co et 8

Torthern Ordnanco Co

Certer oul Co.

Nelson Bros.

J. W. Sorrels 
TABLE 2.-Oil tests and wells shown on fence diagram and geologic sections-Continued

\begin{tabular}{|c|c|c|c|c|c|c|c|}
\hline$\underset{\text { parish }}{\text { County or }}$ & Well & Company or driller & Wellname & $\begin{array}{c}\text { County or } \\
\text { parish }\end{array}$ & Well & Company or driller & Well name \\
\hline \multicolumn{4}{|c|}{ Missouri } & \multicolumn{4}{|c|}{ Tennessee-Continued } \\
\hline \multirow[t]{2}{*}{$\begin{array}{l}\text { Butler } \\
\text { New Madrid. } \\
\text { Do } \\
\text { Pemiscot...... } \\
\text { Stoddard.... } \\
\text { Do }\end{array}$} & \multirow[t]{2}{*}{$\begin{array}{l}6614 \\
6809 \\
8882 \\
7222 \\
8573- \\
9205 \\
\end{array}$} & \multirow[t]{2}{*}{$\begin{array}{l}\text { Coastal Development Co- } \\
\text { Cordova-Union Oil Corp.-- } \\
\text { U.S. Bureau of Mines.... } \\
\text { Strake Petroleum, Inc...- } \\
\text { M. H. Marr } \\
\text { G. E. Kinder et al. }\end{array}$} & \multirow[t]{2}{*}{$\begin{array}{l}\text { J. P. Pearson } 1 . \\
\text { E. Phillips 1. } \\
\text { R. B. Oliver, Jr. } 1 . \\
\text { T. P. Russell 1. } \\
\text { W. J. Crutcher } 1 . \\
\text { Rehms 1. }\end{array}$} & $\begin{array}{r}\text { Shelby } \\
\text { Do........... } \\
\text { Do......... }\end{array}$ & $\begin{array}{l}\text { Sh:L-5 } \\
\text { Sh:0-169...... } \\
\text { Sh: U-12_..... }\end{array}$ & $\begin{array}{l}\text { E. R. Owen, trustee } \\
\text { Memphis Light, Gas \& } \\
\text { Water Div. } \\
\text { Lion O1l \& Refining Co..- }\end{array}$ & \multirow[t]{2}{*}{$\begin{array}{l}\text { Crumpler 1. } \\
\text { Memphis Light, Gas \& } \\
\text { Water Div. 25. } \\
\text { Bateman 1. }\end{array}$} \\
\hline & & & & \multirow{2}{*}{\multicolumn{4}{|c|}{ Texas }} \\
\hline \multicolumn{4}{|c|}{ Tennessee } & & & & \\
\hline $\begin{array}{l}\text { Dyer } \\
\text { Fayette......... } \\
\text { Hardeman. }\end{array}$ & $\begin{array}{l}\text { Dy: } Q \mathrm{G}-1 \\
\text { Fa:J-1 } \\
\text { Hr: } \mathrm{G}-32\end{array}$ & $\begin{array}{l}\text { Henderson Oil Co } \\
\text { Lazarov \& Robilio Oil Co } \\
\text { W. Atkeison Well Supply }\end{array}$ & $\begin{array}{l}\text { Field } 1 . \\
\text { Beasley } 1 . \\
\text { W. G. Capshaw water }\end{array}$ & $\begin{array}{r}\text { Bowie. } \\
\text { Do } \\
\text { Cass... }\end{array}$ & $\begin{array}{l}\text { BD-1620701..- } \\
\text { BD-1644102..- } \\
\text { DB-1659302...- }\end{array}$ & $\begin{array}{l}\text { J. K. Wadley } \\
\text { Permac Oil \& Gas Co., } \\
\text { Inc. Oll \& Refining Co } \\
\text { Atlas Oll \& Re }\end{array}$ & $\begin{array}{l}\text { R. C. Vollmer } 1 . \\
\text { Tidwell } 1 . \\
\text { Laura Thomas } 1 .\end{array}$ \\
\hline $\begin{array}{l}\text { Henderson.... } \\
\text { Lake........ }\end{array}$ & $\begin{array}{l}\mathrm{He}: \mathrm{K}-3 \\
\mathrm{Lk}: \mathrm{E}-17\end{array}$ & $\begin{array}{l}\text { Co. } \\
\text { J. S. Lewis \& Associates } \\
\text { Jack W. Frazier \& Cari }\end{array}$ & $\begin{array}{l}\text { well. } \\
\text { o. H. Roberts } 1 . \\
\text { Sam Hays } 1 .\end{array}$ & $\begin{array}{l}\text { Do } \\
\text { Do......... } \\
\text { Do...... }\end{array}$ & $\begin{array}{l}\text { DB-1664404..- } \\
\text { DB-3503302... } \\
\text { DB-3505502_.. }\end{array}$ & $\begin{array}{l}\text { Arkla Oil Co } \\
\text { Humble Oil \& Refining Co. } \\
\text { Max Agress. }\end{array}$ & $\begin{array}{l}\text { Brook Brothers } 1 . \\
\text { E. Turner } 1 \text {. } \\
\text { Clark \& Boise Lumber }\end{array}$ \\
\hline $\begin{array}{l}\text { Lauderdale... } \\
\text { McNairy } \\
\text { Madison.-...- }\end{array}$ & 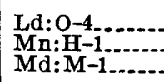 & $\begin{array}{l}\text { Benz. } \\
\text { Raymond Gear........ } \\
\text { Stephens Petroleum Co... } \\
\text { Layne-Central Co. }\end{array}$ & $\begin{array}{l}\text { T. A. Lee. } 1 . \\
\text { Petrie 1. } \\
\text { U.S. Geol. Survey }\end{array}$ & 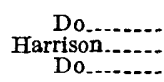 & $\begin{array}{l}\text { DB-3506303.. } \\
\text { LK-3520503... } \\
\text { LK-3536204... }\end{array}$ & $\begin{array}{l}\text { Joe G. Strahan } \\
\text { D. E. \& R. T. Whelan... } \\
\text { Paul Scott \& R. E. Ken- }\end{array}$ & $\begin{array}{l}\text { Mrrs. Sioan Taylor } 1 . \\
\text { Crockett } 1 . \\
\text { C. A. Bell } 1 .\end{array}$ \\
\hline Do.... & $\mathrm{Md}: \mathrm{N}-\mathbf{1}$ & .....do........... & $\begin{array}{l}\text { U.S. Geol. Survey } \\
\text { T-1-M. }\end{array}$ & Marion & $\mathrm{SX}-3512102 \ldots$ & $\begin{array}{l}\text { nedy } \\
\text { Magnolia Petroleum Co... }\end{array}$ & S. L. Orr 1 . \\
\hline
\end{tabular}

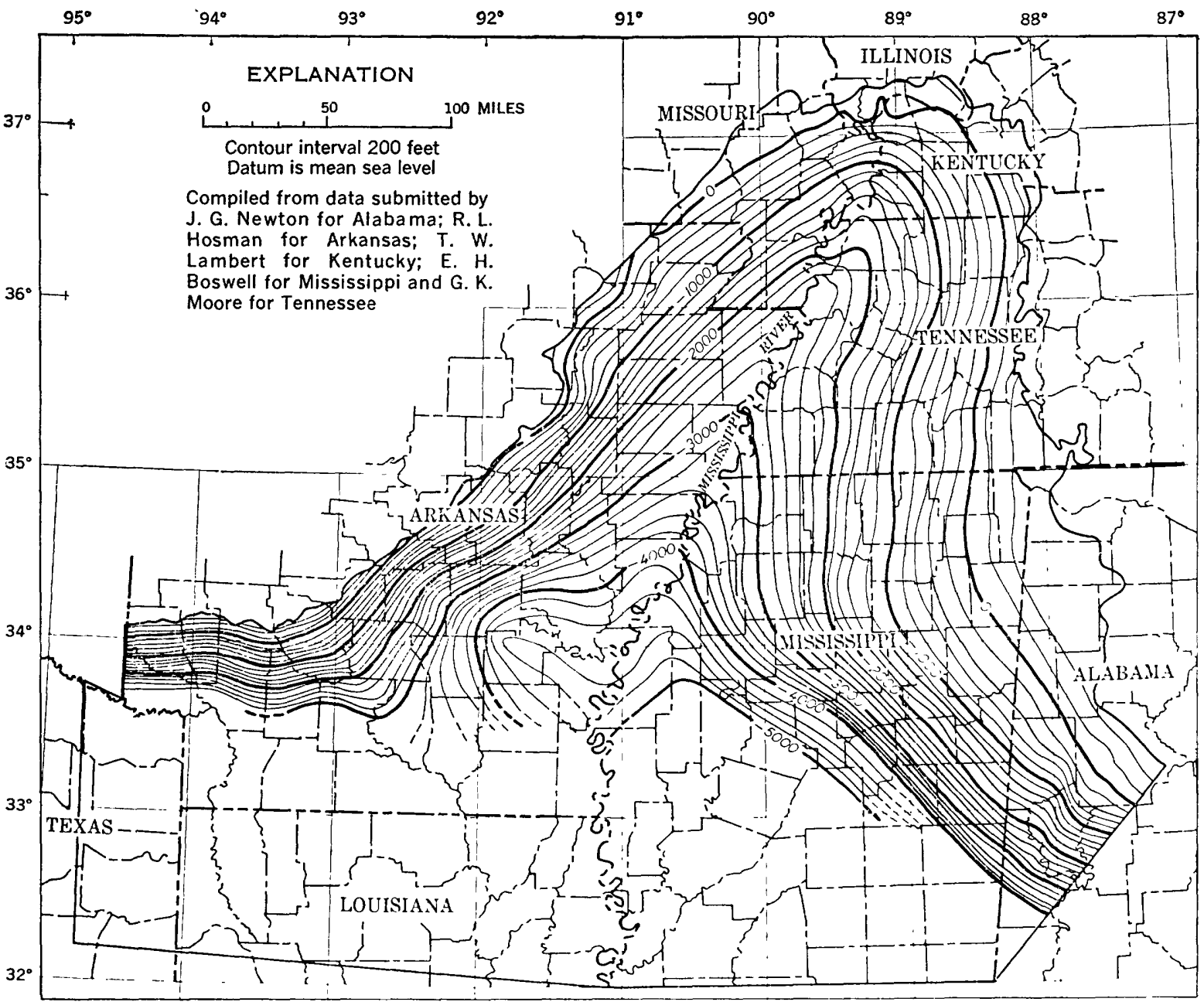

Figure 4.-Contour map showing conflguration of the top of the Paleozolc rocks. 


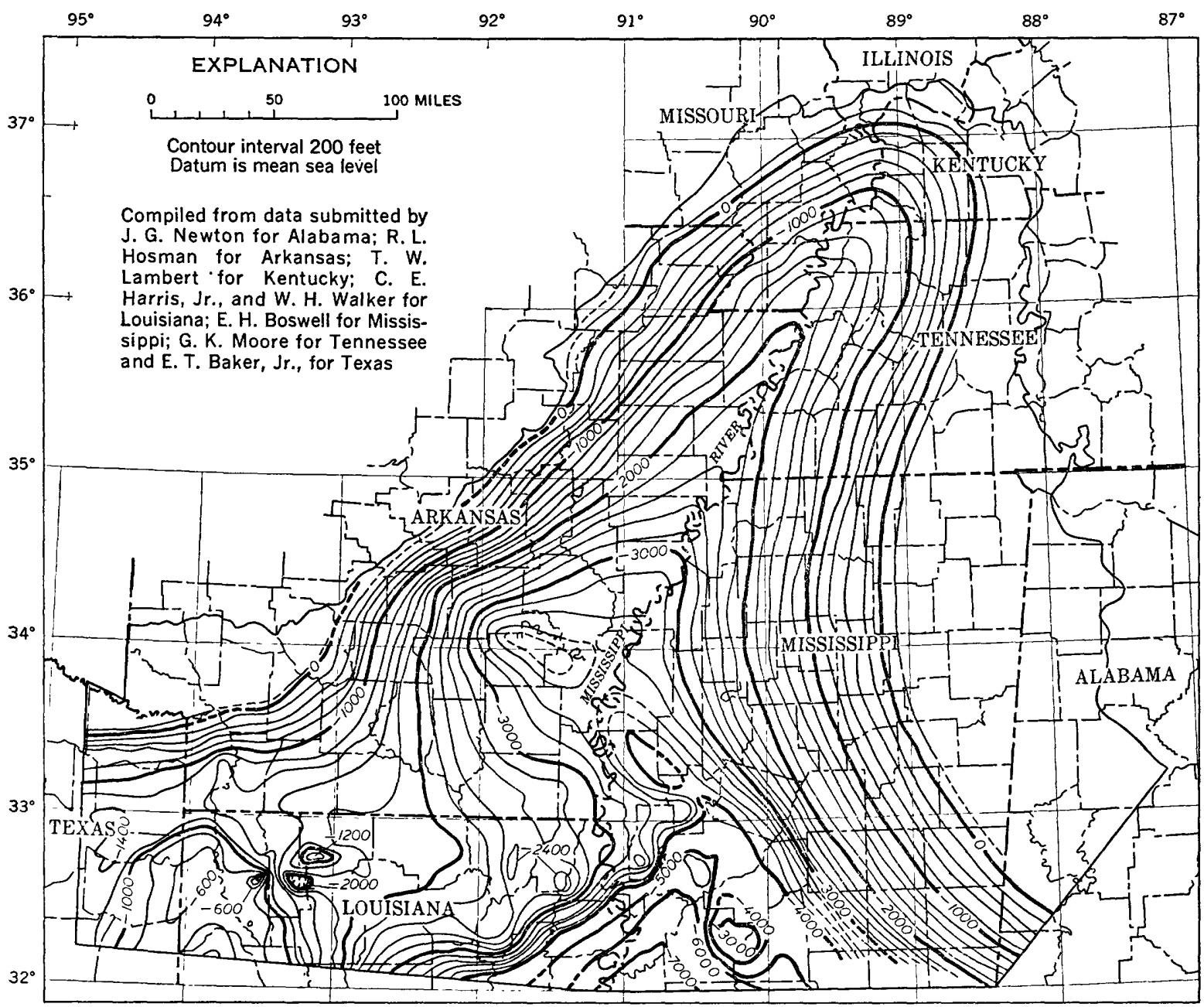

Figure 5,-Contour map showing configuration of the top of the Cretaceous 8ystem.

Two other formations of Early Cretaceous age, the Goodland Limestone (Hill, 1891, p. 504, 514) and the Kiamichi Formation (Hill, 1891, p. 504, 515) overlie the Trinity Group and have a combined maximum thickness of about 70 feet. As these two units crop out in only a very small area in Arkansas near the Oklahoma State line, occur in the subsurface only in northeastern Texas and a small area in southwestern Arkansas, and are not a source of ground water, they are not treated further in this report.

\section{Trinlty Group}

The Trinity Group (Hill, 1888, p. 188) in Arkansas consists in ascending order, of the Pike Gravel (Miser and Purdue, 1918a, p. 20), the Delight Sand (Imlay, 1944), the Dierks Limestone (Miser and Purdue, 1918a, p. 21), the Holly Creek Formation (Vanderpool, 1928, p. 1079-1080)-including the Ultima Thule Gravel Member (Miser and Purdue, 1918a, p. 21), the De Queen Limestone (Miser and Purdue, 1918a, p. 22), and the Paluxy Sand (Hill, 1891, p. 504). This differentiation applies only in the immediate vicinity of the outcrop. The thickness of the group in outcrop is about 1,500 feet, and it may exceed 2,500 feet in the subsurface.

The Paluxy Sand is the most important water-bearing unit in the Trinity Group. The Pike Gravel and the Ultima Thule Gravel Member of the Holly Creek Formation yield moderate quantities of fresh water to wells in and near their outcrops.

\section{UPPER CRITACEOUS SERIES}

The entire Mississippi embayment was inundated by the Late Cretaceous sea to a point at least 20 miles north of Cairo, Ill. Before the sea retreated at the end of the Cretaceous Period, hundreds of feet of sediment were deposited in the embayment. The Upper Cretaceous strata are thickest along the axis and in the southern part of the embayment. They thin eastward and westward toward the flanks and northward toward the apex of the trough. These rocks consist predominantly of sand, clay, marl, and chalk that are mostly of marine origin. Generally, aquifers of the Upper Cretaceous contain fresh water in and near their 
outcrops, and the degree of mineralization in the water increases downdip.

The Upper Cretaceous beds crop out in a wide band along the entire eastern flank of the embayment, in the northeast corner of Texas, and in the southwest corner of Arkansas. A small outcrop occurs along the Fall Line in northeastern Arkansas, but elsewhere along the western flank the Upper Cretaceous rocks are overlapped by younger sediments.

Tuscaloosa Group

The basal Upper Cretaceous beds on the eastern side of the embayment originally were assigned to the Tuscaloosa Formation (Smith and Johnson, 1887, p. 18). These beds in Alabama and Mississippi now constitute the Tuscaloosa Group (originally defined by Monroe and others, 1946, p. 191; redefined by Drennen, 1953a, p. 528), which includes the Coker and Gordo Formations. In the subsurface of central Mississippi and western Alabama, a basal unit known as the massive sand is also included in the group.

In Tennessee and Kentucky the basal Cretaceous beds, lithologically similar to those of the Tuscaloosa Group, remain assigned to the Tuscaloosa Formation. These beds may be as much as 180 feet thick (MacCary, 1960, written communication) and consist of wellrounded pebbles ranging in size from 1 inch to 6 inches. They also contain varying amounts of sand and clay. A hard conglomerate is present in places where the pebbles, mostly chert, are cemented with iron oxide. The Tuscaloosa Formation, largely removed by erosion, is of deltaic origin. Although the formation is not extensive, it does yicld moderate amounts of water to wells in and near its outcrop.

Massive sand.-The term "massive sand," was first used by McGlothlin (1944). The sand was correlated with the Cottondale Formation (of former usage) by Monroe, Conant, and Eargle (1946, p. 210-211) and by Eargle in later work $(1946,1948)$. When Drennen (1953a) reclassified the Tuscaloosa Group, he abandoned the term "Cottondale Formation," formerly applied to the basal unit of the group, because the deposits assigned to this unit were included in the redefined Coker Formation. Drennen (1953, p. 530) describes the Coker Formation as being "correlative with that part of the lower Tuscaloosa above the massive sand." Although the term "Cottondale Formation" was abandoned, the informal term "massive sand" is still used for the basal sand unit of the Tuscaloosa Group in western Alabama and central Mississippi.

Drennen (1953a, table 2) tentativcly correlates the massive sand with the Vick Formation (Conant, 1946), which crops out only in Bibb County, Ala. The Vick Formation, however is Early(?) Cretaceous (Monroe,
1955 , p. 13), whereas the massive sand is probably Late Cretaceous. Until the massive sand is shown to be the subsurface equivalent of the Vick Formation or a suitable geographic name is designated, the informal name "massive sand" is applied to the unit. Whether this unit is of formational rank, is a basal member of the Coker Formation, or is a part of the Eoline Member of the Coker Formation remains to be determined.

The massive sand is "a series of medium- to coarsegrained sands ***" (according to McGlothlin, 1944, p. 40). Interbedded shale and clay occur in the thick beds of coarse sand, chert, and quartz gravel which compose the main body of the unit. The thickness of the massive sand ranges from zero at its northern limit, slightly south of the 34th parallel, to a possible maximum of 500 feet in the southern part of the region. The massive sand overlies beds of Early Cretaceous age in central Mississippi and western Alabama, and northward it overlies Paleozoic rocks. Although the massive sand is not generally used as a source of ground water, it is potentially one of the most important aquifers in the embayment.

Coker Formation.-The Coker Formation (originally defined by Monroe and others, 1946, p. 197-200; redefined by Drennen, 1953a, p. 532-536) ranges in thickness from a few feet to about 400 feet (excluding the massive sand) in the subsurface in Alabama and central Mississippi. In Alabama, the Coker has been subdivided into the Eoline Member and an upper unnamed member.

The Eoline Member (Monroe and others, 1946, p. 194-197) consists of thin-bedded clay, sandy clay, shale, and sand, mostly of marine origin; subordinate beds of sand occur throughout the unit. The overlying unnamed member is composed of multicolored clay and shale containing subordinate sand beds. The Coker Formation lies upon the massive sand and upon Paleozoic rocks where the massive sand is absent.

Although the Coker Formation is not extensively used for ground-water supplies, it seems to be a potential source in many areas in Alabama and Mississippi.

Gordo Formation.-The Gordo Formation (Monroe and others, 1946 , p. 200-204) generally ranges in thickness from 100 to 400 feet in the subsurface. It is composed of thick beds of sand containing gravel in the lower part and multicolored clay and shale interbedded with sand in the upper part. It is absent in the subsurface in northwestern Mississippi. The basal gravel of the Gordo Formation rests unconformably on the clays of the upper unnamed unit of the Coker Formation.

The Gordo Formation is an important aquifer in Alabama and Mississippi. 
Woodbine Formation

The Woodbine Formation (Hill, 1901, p. 293) is the basal unit of the Upper Cretaceous Series in northeastern Texas, northern Louisiana, and southern Arkansas and lies unconformably upon Lower Cretaceous rocks. It has been correlated with the Tuscaloosa Group on the eastern side of the region. The formation reaches a maximum thickness of about 350 feet in the subsurface and consists of sand, clay, gravel, and some reworked volcanic material. The only outcrop in the area of study is in southwestern Arkansas. The Woodbine yields small quantities of water to domestic wells in and near its outcrop.

Eagle Ford Shale

The Eagle Ford Shale (Hill, 1887, p. 298) overlies the Woodbine Formation in Louisiana and Texas but does not crop out in the embayment. It consists of several hundred feet of dark-colored shale, sandy shale, and subordinate beds of sand. The formation is not present on the Sabine uplift, where it has been removed by erosion. The Eagle Ford Shale does not yield water to wells in the embayment.

\section{MaShan Formation}

The McShan Formation (Monroe and others, 1946, p. 204-207), probably equivalent to the Eagle Ford Shale, crops out in Alabama and Mississippi, where it reaches a thickness of 200 feet or more in the subsurface. It consists of laminated micaceous glauconitic gray clay, fine sand, and lenticular beds of fine to medium glauconitic sand. The formation is overlapped by the Eutaw Formation in northern Mississippi and is absent farther north.

In subsurface mapping the McShan is generally included in the lower part of the Eutaw Formation. The McShan is an important aquifer in eastern Mississippi and western Alabama.

Eutaw Formation

In the subsurface in Tennessee, Mississippi, and Alabama the Eutaw Formation (Hilgard, 1860, p. 61) ranges in thickness from zero to more than 400 feet. The main body of the formation is composed of gray clay interbedded with fine glauconitic sand. Thin beds of fine to medium glauconitic sand are common and are fairly persistent near the base of the formation, which is normally marked by a thin bed of fine gravel. The sands are commonly crossbedded or show distinct stratification. A persistent sand at the top of the formation, known as the Tombigbee Sand Member (Hilgard, 1860 , p. 61), is massive, highly glauconitic, calcareous, and fossiliferous in the upper part. The Eutaw Formation overlies the McShan Formation in Alabama and Mississippi, where the contact generally can be recognized on the outcrop. In the subsurface, however, the two units are generally mapped together as the Eutaw Formation. The Eutaw Formation is an important aquifer in eastern Mississippi and western Alabama.

\section{Tokdo Formation}

The Tokio Formation (originally defined by Miser and Purdue, 1918a, p. 19, 24; restricted by Dane, 1926) in Arkansas and northern Louisiana ranges in thickness from 50 to more than 300 feet in the subsurface and is probably equivalent to the Eutaw Formation. The Tokio is composed mainly of poorly sorted crossbedded yellow and white sands, gray sandy clay, and a basal bed of novaculite gravel. Gravel lenses are scattered throughout the formation, and the gray clay contains varying amounts of lignite. The Tokio Formation unconformably overlies the Woodbine Formation in the outcrop area in southwestern Arkansas. It supplies moderate quantities of water to numerous wells in and near its outcrop.

Blossom sand and Bonham Marl

The Blossom Sand (Gordon, 1909, p. 371, 373) and Bonham Marl (Stephenson, 1927, p. 8) in northeastern Texas are equivalent to the Tokio Formation in Arkansas (Dane, 1929, p. 42-43, 81) and Louisiana and to the Eutaw Formation in Alabama, Mississippi, and Tennessee. Only the Blossom Sand is hydrologically important. The Blossom has a maximum thickness of about 350 feet in the subsurface. It consists of interbedded sand and clay and is predominantly clay in areas where it is thickest. Its usefulness as an aquifer is restricted to the vicinity of the outcrop. Selma Group

In Alabama and Mississippi the Selma Group (Smith, Johnson, and Langdon, 1894, p. 15) includes the Upper Cretaceous formations between the top of the Eutaw Formation and the base of the Midway Group. These formations in western Alabama and eastern Mississippi, in ascending order, are the Mooreville Chalk, the Demopolis Chalk, the Ripley Formation, and the Prairie Bluff Chalk. In the northern part of Mississippi the Selma Group, in ascending order, includes the Coffee Sand, the Demopolis Chalk, the Ripley Formation, and the Owl Creek Formation.

The formations of the Selma Group are equivalent to those in Arkansas, northern Louisiana, and northeastern Texas which are between the top of the Tokio Formation or the Blossom Sand and the base of the Midway Group.

Mooreville Chalk.-The Mooreville Chalk (Stephenson, 1917, p. 246), including the Arcola Limestone Member (Stephenson and Monroe, 1938, p. 1655-1657) at the top, has a maximum thickness of more than 250 feet in central and southern Mississippi and western Alabama. It is an impure chalk or chalky marl containing scattered thin beds of very fine sand. Some 
sandy zones are extremely glauconitic, especially those in the upper part of the formation. The Arcola Limestone Member is a moderately hard limestone, commonly penetrated by marine borings.

The Mooreville Chalk is equivalent to the Brownstown Marl of Arkansas, northern Louisiana, and northeastern Texas. In northern Mississippi the Mooreville grades into sand and becomes the lower part of the Coffee Sand. The Mooreville Chalk is not an aquifer.

Coffee Sand.-The Coffee Sand (Safford, 1864, p. 361 ) in Tennessee and northern Mississippi is a facies equivalent of the Mooreville Chalk and the lower part of the Demopolis Chalk. Near its outcrop the Coffee Sand may be as much as 200 feet thick. It is made up largely of a series of stratified and crossbedded sands and clays. The sands are generally fine and varicolored; in many places they contain an abundance of mica and in some places glauconite and pyrite. The clays are highly carbonaceous and contain an abundance of plant remains. The Coffee Sand is an important aquifer.

Demopolis Chalk.--The Demopolis Chalk (Smith, 1888), including the Bluffport Marl Member (Monroe, 1956 , p. 2740-2742) at the top, is about 500 feet thick in central Mississippi and western Alabama. The Bluffport Marl Member has a maximum thickness of about 50 feet.

The Demopolis Chalk in Mississippi and Alabama is a relatively pure chalk; the Bluffport Marl Member at the top is an impure chalk which grades into the overlying Ripley Formation. Northward, the upper 250 feet of the chalk becomes clayey, and the remainder becomes a part of the Coffee Sand. In Tennessee this clayey unit is called the Demopolis Formation. The Demopolis does not contain any aquifers.

Ripley Formation.-The Ripley Formation (Hilgard, 1860, p. 62) in Alabama, Mississippi, and Tennessee has a maximum thickness of about 400 feet. In northern Mississippi the formation includes, in ascending order, the transitional clay, Coon Creek Tongue, McNairy Sand Member, and Chiwapa Member. In Tennessee it includes, in ascending order, the Coon Creek Tongue and the McNairy Sand Member. Only the McNairy Sand occurs in Kentucky, Illinois, and Missouri, and it has formational status in these States. The undifferentiated Ripley Formation typically consists of clay, sandy clay, sand, and thin beds of sandstone.

A zone of clay above the Demopolis Chalk was described as the transitional clay by Conant (1941, p. 22), who assigned the unit to the Ripley Formation. The transitional clay is in the same stratigraphic position and may be the lateral facies of the Bluffport Marl
Member of the Demopolis Chalk. The units are lithologically similar. Sohl $(1960$, p. 11) states that the transitional clay “*** consists primarily of clays which become increasingly arenaceous and argillaceous upward as they grade into sand of the Ripley and increasingly calcareous downward as they grade into the Demopolis Chalk." The transitional clay in outcrop averages less than 50 feet thick.

The Coon Creek Tongue (Wade, 1917, p. 74) is about 180 feet thick near the outcrop area in northern Mississippi (Parks, 1960, p. 67). The lower part of the unit grades into the underlying transitional clay of the Ripley Formation; the main body of the typical Coon Creek Tongue is a dark-gray glauconitic micaceous fossiliferous fine sand interbedded with clay.

The McNairy Sand Member (Stephenson, 1914, p. 22 ) is about 200 feet thick near the Mississippi-Tennessee State line. Southward, it underlies the Chiwapa Member and gradually grades into the upper marine sand and clay of the Ripley Formation in northern Mississippi. The McNairy Sand Member is a medium to coarse sand, which is white to brown in subsurface samples; in the outcrop it is varicolored and crossbedded, and characteristically includes indurated layers of tubular ferruginous sandstone.

The Chiwapa Member (Mellen, 1958, p. 49) occurs in northern Mississippi. The member " *** is characteristically a 'bored' or 'horsebone' limestone or calcareous sandstone, an irregularly indurated stratum of shallow marine sediment approximately 80 feet in thickness at the top of the Ripley, and it can be traced for a north-south distance of 85 miles, more or less." The Chiwapa Member crops out from Tippah County, Miss., southward to Clay County.

Sands of the Ripley Formation, particularly the McNairy Sand Member and the Chiwapa Member, are excellent aquifers.

Prairie Bluff Chalk and Owl Creek Formation.-The Prairie Bluff Chalk (Winchell, 1857, p. 84) is the uppermost unit of the Upper Cretaceous Series in western Alabama and Mississippi. In extreme northern Mississippi it is represented by the Owl Creek Formation (Hilgard, 1860, p. 85), a facies which extends into Tennessee and Missouri and possibly into Kentucky and Illinois. The Prairie Bluff Chalk is from 30 to 70 feet thick and the Owl Creek Formation is about 45 feet thick in the subsurface. The Prairie Bluff Chalk is a gray to white slightly sandy massive chalk which grades northward into the highly fossiliferous dark-gray fine micaceous silty sand and clay of the Owl Creek Formation. The formations rest unconformably on the Ripley Formation (the McNairy Sand in Missouri), and underlie unconformably the Midway Group. Neither formation is an aquifer. 
Demopolis Formation

The unit which has been called the "Selma Clay" in Tennessee (Glenn, 1906, p. 26) is here called the Demopolis Formation. Recent mapping of the Cretaceous sediments by E. E. Russell for the Tennessee Division of Geology has shown that this unit, which overlies the Coffee Sand and underlies the Ripley Formation in Tennessee, is the upper part of the Demopolis Chalk of the Selma Group in Mississippi. Russell ${ }^{1}$ (written communication) states that "the unit is composed of massive calcareous clays, marls, and some chalky materials." He calls the unit the Demopolis Formation, and the name is appropriate.

Brownstown Marl

The Brownstown Marl (originally defined by Hill, 1888, p. 86-87; restricted by Dane, 1926) lies unconformably on the Tokio Formation in Arkansas and northern Louisiana and on the Blossom Sand in northeastern Texas. It is equivalent to the Mooreville Chalk of Alabama and Mississippi. The Brownstown Marl has a maximum thickness of about 280 feet in the subsurface in southwestern Arkansas and consists of dark-gray to tan fossiliferous calcareous clay, gray marl, sand, and sandy clay. It yields small amounts of highly mineralized water to a few wells in its outcrop. Ozan Formation

The Ozan Formation (Dane, 1926) has a maximum thickness of about 200 feet in southwestern Arkansas. It varies from fossiliferous gray sandy marl, sand, sandy limestone, and clay to chalk and marl. A layer of glauconitic sand occurs at the base. The Ozan Formation unconformably overlies the Brownstown Marl. It yields small amounts of highly mineralized water to a few wells in southwestern Arkansas.

\section{Annona Chalk}

The Annona Chalk (originally defined by Hill, 1894, p. 308 ; restricted by Dane, 1926) overlies the Ozan Formation in southwestern Arkansas and the Brownstown Marl in northern Louisiana and in parts of northeastern Texas. The Annona is as much as 100 feet thick in Arkansas and as much as 400 feet thick in Louisiana and Texas, where the lower part is probably equivalent to the Ozan Formation. The Annona is a massive hard bluish-gray to white fossiliferous chalk, and in Texas some chalky marl beds occur in the lower part. The Annona is equivalent to part of the Demopolis Chalk of Alabama and Mississippi. It does not yield water to wells.

Marlbrook or Taylor Marl

The Marlbrook Marl (orignially defined by Hill, 1888, p. 84-86; restricted by Stephenson, 1927, p. 15) occurs in Louisiana and Arkansas. In Texas its

\footnotetext{
1 Russell, E. E., Professor, Dept. of Geology, Mississippi State University, Starkville, Miss.
}

equivalent is the upper part of the Taylor Marl. The Marlbrook has a maximum thickness of about 300 feet in the subsurface. It is a fossiliferous chalky blue to gray marl containing some glauconitic sand and, locally, thin beds of chalk. It does not yield water to wells.

Navarro Group

The Navarro Group (Shumard, 1861, p. 189) in northeastern Texas has not been subdivided. It includes the units between the top of the Taylor Marl and the base of the Midway Group. The Navarro Group is equivalent to the Ripley Formation and the Prairie Bluff Chalk or the Owl Creek Formation of Alabama, Mississippi, and Tennessee.

In Texas, west of the area of study, the Navarro Group has been divided, in ascending order, into the Neylandville Marl, Nacatoch Sand, Corsicana Marl, and Kemp Clay. In Arkansas and Louisiana the units between the top of the Marlbrook Marl and the base of the Midway Group have not been assigned to a group. These units include, in ascending order, the Saratoga Chalk (Saratoga Clay in Louisiana), Nacatoch Sand, and Arkadelphia Marl.

Saratoga Chalk

The Saratoga Chalk (originally defined by Branner 1898 , p. 53 ; restricted by Dane, 1926), called the Saratoga Clay in Louisiana, is 20 to 60 feet thick in Arkansas and is probably equivalent to the Coon Creek Tongue of the Ripley Formation. It is a white fossiliferous sandy chalk and has a thin glauconitic and phosphatic zone at its contact with the Marlbrook Marl, which it overlies unconformably. It does not yield water to wells.

\section{Nacatoch Sand}

The Nacatoch Sand (originally defined by Veatch, 1905 , p. 180 , 183 ; restricted by Dane, 1929 , p. 117119) in Arkansas and Louisiana is virtually equivalent to the Ripley Formation. It ranges in thickness from about 100 to 500 feet in the subsurface. It is generally a massive crossbedded yellowish to gray fine sand, which is in part glauconitic and which is interbedded with hard sandy limestone and light-gray clay and marl; clay and marl are more abundant in the lower part of the formation. The Nacatoch Sand supplies moderate quantities of water to wells in its outcrop area and for several miles downdip.

\section{Arkadelphia Marl}

The Arkadelphia Marl (originally defined by Hill, 1888, p. 53-56; restricted by Dane, 1929 , p. 144-145), the equivalent of the Prairie Bluff Chalk and the Owl Creek Formation, is the uppermost unit of the Upper Cretaceous Series in Arkansas and Louisiana. It has a maximum thickness of about 200 feet in the subsurface. The Arkadelphia Marl consists generally of 
dark-blue fossiliferous marl interbedded with sandy limestone and may be glauconitic and chalky in part. It has an uncomformable but lithologically gradational contact with the underlying Nacatoch Sand. The Arkadelphia Marl does not yield water to wells.

\section{TERTIARY SYSTEM}

The Tertiary System in the Mississippi embayment comprises deposits of the Paleocene, Eocene, Oligocene, Miocene, and Pliocene(?) Series. Tertiary rocks occur either in the subsurface or crop out in about 75 percent of the region. Their maximum thickness is about 7,000 feet at the axis of the embayment at the southern limit of the region. The sediments are mostly unconsolidated and consist mainly of sand, clay, and shale.

The Tertiary System overlies the Cretaceous System with marked unconformity, and it is overlain in most places by alluvial deposits, terrace deposits, or loess, all of Quaternary age.

Several major Tertiary artesian aquifers supply ground water to large areas of the Mississippi embayment.

\section{PALEOCENE SERHES}

The Paleocene Series underlies the Eocene Series and overlies the Upper Cretaceous Series. It is composed of nearly 1,000 feet of sediments, in which dark clay is predominant. The Midway Group constitutes the entire series except in northern Louisiana, where the lower part of the Wilcox Group is included.

\section{Midway Group}

In northern Mississippi, Tennessee, Kentucky, nlinois, Missouri, and northern Louisiana, the Midway Group (Smith, 1886, p. 14) comprises, in ascending order, the Clayton Formation and Porters Creek Clay. In Arkansas, except in the bauxite area, the Midway Group is undifferentiated. In the Arkansas bauxite area and in northeastern Texas the Kincaid and Wills Point Formations compose the group. In central Mississippi and western Alabama the Naheola Formation is included in the Midway, but beds presumed to be equivalent to the Naheola have been assigned to the overlying Eocene Series in other areas. The Naborton and Dolet Hills Formations of Paleocene age in Louisiana, probably partly equivalent to the Naheola Formation, are grouped with the Wilcox on the basis of lithology.

The maximum subsurface thickness of the Midway Group is about 1,000 feet at the axis of the embayment at the southern limit of the region. The thickness near the outcrop area ranges from a known minimum of 180 feet in Kentucky to about 600 feet in parts of Texas, Louisiana, Arkansas, Mississippi, and Alabama.

The Midway Group is composed predominantly of marine clay and shale but includes subordinate sand and limestone beds. The basal limestone of the Clayton
Formation unconformably overlies the Cretaceous System. The contact with the overlying Wilcox Group is indeterminate in most places, but in Alabama and adjacent parts of Mississippi the contact between the basal beds of the Wilcox Group and the top of the Naheola Formation has been mapped. In other areas the contact may be defined by weathered zones, deposits of kaolinitic material, bauxite, residuum, or other lithologic evidence of unconformity.

Figure 6 is a contour map showing configuration of the sandy zone immediately above the Porters Creek Clay. The base of this zone, as shown on electric logs, is used as the top of the Midway Group.

Clayton Formation.-The Clayton Formation (Langdon, 1891 , p. 595) is commonly about 35 feet thick, but in many places in the outcrop area it is much thinner or missing because of overlap by the Porters Creek Clay.

The Clayton Formation is composed mostly of limestone, calcareous sand, and sandstone, all of marine origin. In some places it is lithologically very similar to underlying Cretaceous sediments but may be differentiated paleontologically. In other places a basal conglomerate marks the contact. Conant (1941, p. 27-32) recognizes two units in the Clayton Formation in northern Mississippi, a basal limestone and marl member and an upper member. Weathered exposures in northern Mississippi are composed mostly of dark-red sand, generally ferruginous and glauconitic. The contact with the overlying Porters Creek Clay is generally gradational. The Clayton Formation contains no important aquifers.

Kincaid Formation.-The Kincaid Formation (Gardner, 1933b, p. 744) is the basal unit of Paleocene age in northeastern Texas and in the Arkansas bauxite area. The Kincaid rests unconformably on Upper Cretaceous and older rocks. In the Arkansas bauxite area, where the formation is apparently very irregular in thickness, it directly overlies the Paleozoic in some places (Gordon, Tracey, and Ellis, 1958, p. 13-25). The average thickness of the formation in the embayment is about 30 feet. The formation consists predominantly of glauconitic sand, clay, and limestone, all of marine origin. In places there is a basal conglomerate composed of reworked material from underlying beds. The Kincaid Formation is correlative with the Clayton Formation.

Sandy beds in the Kincaid Formation yield small quantities of water to wells.

Porters Creek Clay.-The Porters Creek Clay (Safford, 1864, p. 361, 368), called the Porters Creek Formation in Alabama, is less than 180 feet thick in the subsurface in western Kentucky but thickens to almost 1,000 feet near the axis of the embayment at the southern 


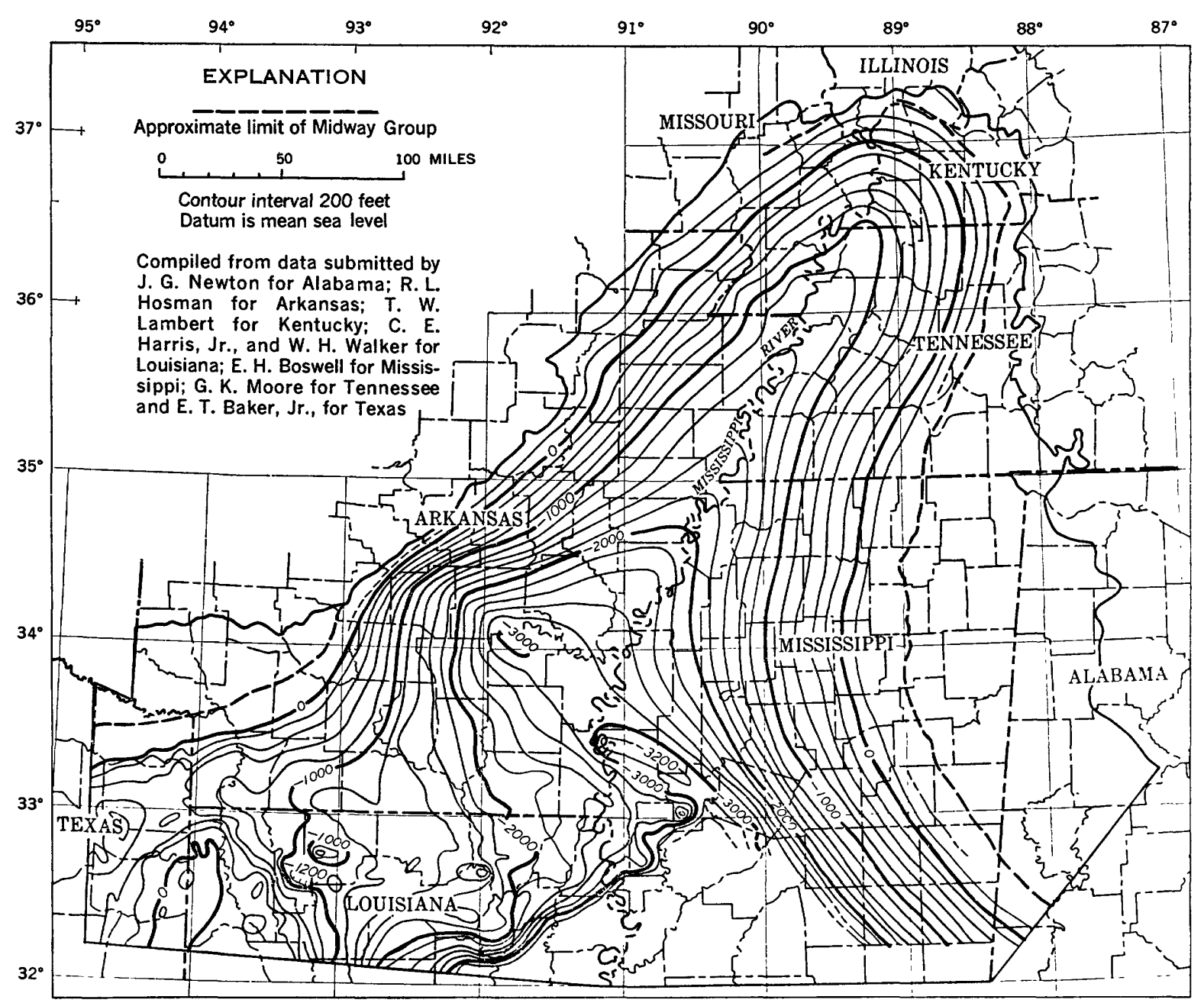

Fiourr 6.-Contour map showing configuration of the base of sandy zone abore the Porters Creek Clay.

limit of the region. The formation thins markedly to less than 100 feet over some structural highs in the subsurface but elsewhere changes in thickness are gradual.

In most of the embayment the Porters Creek is very dark gray or black blocky clay. Subordinate beds of sand occur in several places, and the Tippah Sand Lentil (Lowe, 1915, p. 64) is a recognized member in extreme northern Mississippi. Ferruginous concretions and layers are common. In the northern part of the region the upper part of the formation is composed of interbedded or laminated fine sand and gray clny. The Porters Creek does not include any important aquifers.

In Alabama and southeastern Mississippi, the Matthews Landing Marl Member (Smith, 1886, p. 13), a very glauconitic sandy fossiliferous marl or sandstone that is generally less than 10 feet thick, is the uppermost unit of the Porters Creek. It is a well-defined stratigraphic marker in western Alabama and castern Mississippi, where its faun and marine lithology are distinctive. Northward, it becomes a thin marl and loses its identity in Winston County, Miss.

Wills Point Formation.-The Wills Point Formation (originally defined by Penrose, 1890, p. 19; redefined by Plummer, 1927) is the uppermost formation of Paleocene age in northeastern Texas and in the Arkansas bauxite area. It is underlain by the Kincaid Formation and overlain by the Wilcox Formation or Group. The Wills Point is predominantly gray to green calcareous clay of marine origin. The upper part of the formation is sandy in places and appears to grade into sands of the overlying Wilcox. The avernge thickness of the formation is about 500 feet. The Wills Point Formation is not known to yicld fresh water to wells in the embayment.

Naheola Formation.--In western Alabama nnd eastern Mississippi, the Naheola Formation (Smith, 1886, p. 13) is a part of the Midway Group. The formation thins from about 200 feet in Alabama to less than 100 feet in Mississippi. In western Alabama the Naheola Formation is divided into the Oak Hill Member below and 
the Coal Bluff Marl Member above. In the remainder of the embayment, where the Matthews Landing Marl Member of the Porters Creek Clay has not been identified, beds equivalent to the Naheola Formation are sometimes included in the Porters Creek or, for lithologic reasons, in the overlying Wilcox.

The Oak Hill Member (Toulmin, LaMoreaux, and Lanphere, 1951, p. 42) consists characteristically of thinly laminated fine sand and silty clay. In places, a bed of lignite, defining the contact with the overlying Coal Bluff Marl Member (Smith, 1886, p. 12), forms the top of the member. The Coal Bluff Marl Member is predominantly marine sand and clay, which includes a fossiliferous bed (LaMoreaux and Toulmin, 1959, p. 83).

Sandy beds in the Naheola Formation are water bearing in western Alabama and the adjacent parts of Mississippi but are not important hydrologically in the remainder of the embayment.

\section{EOCENE SERIES}

The Eocene Series crops out or underlies about 70 percent of the embayment. It is thickest in the southeastern part of the region, where marine phases provide a basis for unit differentiation. The Eocene rocks are divided, in ascending order, into the Wilcox Group or Formation, Claiborne Group, and Jackson Group or Formation.

wulcox Group

The Wilcox Group (Crider and Johnson, 1906, p. 5, 9) includes, in ascending order, the Nanafalia Formation, Tuscahoma Sand, and Hatchetigbee Formation in western Alabama and the Berger and Saline Formations and Detonti Sand in the Arkansas bauxite area. In northern Louisiana the Naborton and Dolet Hills Formations of Paleocene age are considered a part of the Wilcox Group. The Wilcox Group is undifferentiated in Arkansas (except in the bauxite area), Illinois, Kentucky, and Tennessee. In Mississippi, Missouri, and northeastern Texas, the Wilcox is considered to be a formation.

Although undifferentiated, the Wilcox in the subsurface of northern Mississippi, northeastern Arkansas, Tennessee, Kentucky, and Missouri contains at least two distinct lithologic units-a lower predominantly sand unit and an upper predominantly shale or clay unit. The sandy unit is called the " 1,400 -foot" sand (Klaer, 1940, p. 92) of the Memphis area (pl. 2), which has been traced for considerable distances in the northern part of the embayment (Schneider and Cushing, 1948 , p. 3). This sand is an important source of ground water in the region.

Nanafalia Formation.-The Nanafalia Formation (Smith, 1886, p. 12), has a maximum thickness of about 230 feet. It is the basal formation of the Wilcox Group in western Alabama, where it consists of sand, marl, and clay. Kaolinitic and bauxitic material is disseminated through the formation in some places. Locally, deposits of bauxite and kaolin occur in the lower part of the Nanafalia Formation or in the equivalent part of the Wilcox. In western Alabama the Nanafalia Formation comprises three members (LaMoreaux and Toulmin, 1959, p. 98), which, in ascending order, are the Gravel Creek Sand Member, the middle member, and the Grampian Hills Member.

According to LaMoreaux and Toulmin (1959, p. 98), the Gravel Creek Sand Member "consists of white to yellow medium- to coarse-grained crossbedded sand with stringers and thin lenses of fine gravel and clay pebbles." It is correlative with the Fearn Springs Member (Mellen 1939, p. 33) of the Wilcox Formation of Mississippi. The Fearn Springs Member includes a basal coarse sand and an upper laminated fine sand and gray clay (Hughes, 1958, p. 148). The middle member of the Nanafalia Formation includes the Ostrea thirsae beds. These beds also occur in the basal part of the Eocene Series in Louisiana (Durham and Smith, 1958, p. 5-6). The Grampian Hills Member of the Nanafalia Formation consists of gray clay and beds of glauconitic sand and sandstone (LaMoreaux and Toulmin, 1959, p. 100).

The Nanafalia Formation and its equivalents in the lower part of the Wilcox form one of the most important aquifers in the Mississippi embayment. The "1,400foot" sand of the Memphis area may be equivalent, in part, to the Nanafalia Formation.

Tuscahoma Sand.-The Tuscahoma Sand (Smith, Johnson, and Langdon, 1894, p. 162-170) is composed of lenticular fine sand, gray clay, and laminated fine sand and clay, all containing some lignite. In western Alabama the formation includes the Greggs Landing Marl Member (Smith, 1886, p. 12) and the Bells Landing Marl Member (Smith, 1883, p. 256). These marine beds become indistinguishable from the rest of the Wilcox Formation northwestward in Mississippi.

The average thickness of the Tuscahoma Sand is about 350 feet. Because of its fine grain size and lenticularity, the Tuscahoma Sand is not used as extensively as a source of water as the Nanafalia Formation.

Hatchetigbee Formation.-The Hatchetigbee Formation (Smith, 1886, p. 10) is the youngest formation of the Wilcox Group in western Alabama. The formation is predominantly gray lignitic clay and fine sand but contains scattered beds of lignite. The Bashi Marl Momber (Heilprin, 1882, p. 158-159), a distinctive fossiliferous marine bed at the base of the formation, overlies the Tuscahoma Sand. The Bashi Marl Member 
has been tentatively identified as far north as southeru Winston County, Miss. (McNeil, 1946, p. 21-22). Lenticular beds of sand are locally important as aquifers. Berger and Saline Formations and Detonti Sand.In the Arkansas bauxite area, the Wilcox Group comprises the Berger and Saline Formations and the Detonti Sand, which have been described in detail by Gordon, Tracey, and Ellis (1958, p. 38-58). Elsewhere in Arkansas, the group has not been divided. The equivalence of these formations to those described in Alabama or Louisiana has not been shown. The Berger Formation is about 25 feet thick in outcrop and is composed of lignitic sand and clay characteristic of the Wilcox; bauxitic and kaolinitic material occurs in beds throughout the formation.

Naborton Formation.-Murray (1948, p. 94-95) describes the Naborton Formation as "calcareous, buff to gray, fine- to medium-grained sands, clays, and lignitic silts." The formation reaches a maximum thickness of about 200 feet. The thin-bedded or laminated structure of the beds and the stratigraphic position of the unit suggest that the Naborton may be partly equivalent to the Oak Hill Member of the Naheola Formation.

The Naborton Formation crops out in a small area in northwestern Louisiana and is extensive in the subsurface. It is not known to contain an aquifer in the embayment, but it is an important source of ground water in DeSoto and Red River Parishes, La.

Dolet Hills Formation.-The Dolet Hills Formation (Murray, 1948, p. 105) consists of fine to medium massive sand and subordinate clay and lignite. It is extensive in the subsurface, has a maximum thickness of 125 feet, and crops out in the same general area as the Naborton Formation. It is probably partly equivalent to the Naheola Formation.

Above the Dolet Hills Formation are undifferentiated beds of sand and clay (Murray, 1948, p. 138) which are also considered to be of Paleocene age. These beds, together with the Naborton and Dolet Hills Formations, are included in the Wilcox Group in Louisiana on the basis of lithology.

Clalborne Group

Rocks of the Claiborne Group (Conrad, 1848, p. 280-283) are known to crop out in all States included in this investigation except Illinois and Missouri. In the northern part of the embayment, some beds previously designated as members of the Wilcox may be members of the Claiborne Group because of the broad overlap by the Claiborne Group in the region.

The maximum thickness of the Clairborne Group, about 2,600 feet, occurs in the subsurface in the southern part of the embayment. The group is composed of marine and nonmarine sand, sandy clay, clay, shale, and limestone. In the southern part of the region, the Claiborne Group can be subdivided into formations, on the basis of marine beds. In the northern part of the region the Claiborne Group is undifferentiated.

The group, in ascending order, is composed of the following units: The Tallahatta Formation, Winona Sand, and Zilpha Clay, and their equivalents - the Carrizo Sand and Mount Selman Formation in Texas and the Carrizo Sand and Cane River Formation in Arkansas and Louisiana; the Sparta Sand; the Cook Mountain Formation; and the Cockfield Formation. In Kentucky and Tennessee the Claiborne Group is undifferentiated.

Tallahatta Formation.-The Tallahatta Formation (Dall, 1898, p. 344) in Alabama and Mississippi is equivalent to the Carrizo Sand and to the Reklaw Member and Queen City Sand Member of the Mount Selman Formation of Texas and to the Carrizo Sand and the lower part of the Cane River Formation of Arkansas and Louisiana.

The Tallahatta Formation in Alabama includes the Meridian Sand Member. In central Mississippi it includes the Meridian Sand Member, Basic City Shale Member, and Neshoba Sand Member. In northern Mississippi it includes the Holly Springs Sand Member.

The Tallahatta Formation in western Alabama and eastern Mississippi averages about 90 feet in thickness. In north-central Mississippi it thickens to about 200 feet in outcrop, and it may reach a thickness of 400 feet in the subsurface.

The Meridian Sand Member (Lowe, 1933, p. 1, 105-106) of the Tallahatta Formation crops out in western Alabama and in Mississippi. It is the basal member of the Claiborne Group and is equivalent to the Carrizo Sand of Arkansas, Louisiana, and Texas. The thickness of the Meridian Sand Member is variable, averaging probably more than 100 feet. Brown (1947, pl. 9) shows the maximum thickness to be 490 feet in the subsurface in Holmes County, Miss.

The Meridian Sand Member is fine to very coarse quartz sand, which is characteristically crossbedded. The contact with the underlying Wilcox Group is determined by the presence of lignitic clay or shale or highly carbonaceous material characteristic of the Wilcox.

The Meridian Sand Member is a productive aquifer in the embayment. The basal part of the " 500 -foot" sand (Klaer, 1940, p. 92) of the Memphis area (pl. 2) probably is equivalent to the Meridian Sand Member.

The Basic City Shale Member (Brown and Adams, 1943 , p. 43) is composed of sparsely fossiliferous lightcolored claystone, siltstone, and shale. Ledges of orthoquartzite (buhrstone) are common. The Basic 
City Shale Member is not an important aquifer except in northwestern Mississippi, where sandy facies of the unit occur.

The Neshoba Sand Member (Thomas, 1942, p. 24) of the Tallahatta Formation occurs in central Mississippi and is about 50 feet thick. It gradually thickens northward and is in the subsurface in central and northwestern Mississippi. The Neshoba Sand Member is typically fine micaceous quartz sand containing some gray clay. It is locally glauconitic but is not known to be fossiliferous. The Neshoba Sand Member is considered by Stenzel $(1952$, p. 32$)$ to be equivalent to the lower part of the Queen City Sand Member of the Mount Selman Formation. The Neshoba Sand Member is an aquifer in some areas in Mississippi.

The Holly Springs Sand Member (Lowe, 1913, p. 23-25) of the Tallahatta Formation in northern Mississippi was originally considered to be a formation of the Wilcox Group in Mississippi, Tennessee, and Kentucky. Foster $(1940$, p. 32,53$)$ restricts the name Holly Springs to beds in Lauderdale County, Miss., that are equivalent to the Tuscahoma Sand in adjoining Alabama. MacNeil (1946, p. 17) states that "the type Holly Springs formation of northern Mississippi, $*^{* *}$ is the nonmarine equivalent of the Tallahatta formation to the south. The name Holly Springs was accordingly abandoned in favor of Tallahatta for all of Mississippi." MacNeil (1947), however, uses the name Holly Springs Sand Member for the entire Tallahatta Formation of northern Mississippi. Brown (1947, p. 34) states that "the outcrops of sand around Holly Springs are exposures of the Meridian sand member of the Tallahatta formation ***."

The use of the name Holly Springs Sand Member probably should be discontinued because of the previous long association of the name with the Wilcox Group, but additional work is needed to determine the stratigraphic relation of this unit to other Eocene units in northern Mississippi.

Carrizo Sand.-The Carrizo Sand (Owen, 1889, p. 70) in Texas, Louisiana, and Arkansas is equivalent to the Meridian Sand Member of the Tallahatta Formation of western Alabama and Mississippi. Like the Meridian Sand Member, the Carrizo varies in thickness because of its deposition on the irregular surface of the Wilcox sediments. The sand probably does not exceed 200 fect in thickness, and in many places it is reported to be absent.

The Carrizo Sand consists of fine to coarse lightgray to brownish-gray micaceous sand. It is an aquifer in the western part of the embayment.

Mount Selman Formation.-The Mount Selman Formation (Kennedy, 1892, p. 45, 52-54), comprises in ascending order, the Reklaw (Wendlandt and Knebel,
1929, p. 1352), Queen City Sand (Kennedy, 1892, p. 50), and Weches Greensand (Wendlandt and Knebel, 1929, p. 1356) Members, or all strata above the top of the Carrizo Sand and below the base of the Sparta Sand. The Mount Selman Formation is equivalent to the Cane River Formation of Louisiana and Arkansas and to the Tallahatta Formation (except the Meridian Sand Member), Winona Sand, and Zilpha Clay of Mississippi. The Mount Selman Formation averages about 300 feet in thickness.

Overlying the Carrizo Sand and separated from it by a disconformity is the Reklaw Member of the Mount Selman Formation, a sequence of dark-colored stratified shales and sands that are commonly fossiliferous, micaceous, and glauconitic. Thin lenses of limonite normally are associated with the glauconite. The member is sandy in places, which makes it difficult to separate the Reklaw from the overlying and underlying units. The thickness of the Reklaw Member probably does not exceed 125 feet.

The Queen City Sand Member of the Mount Selman Formation, overlying the Reklaw Member, consists predominantly of gray to grayish-brown fine to medium sand interbedded with layers of dark carbonaceous shale, silt, and impure lignite. The sands are crossbedded and lenticular. Beds or lenses of glauconite reportedly occur near the middle of the member. The thickness of the Queen City Sand Member in northeastern Texas is not known, but it probably is about 200 feet.

The lower part of the Queen City Sand Member is considered by Stenzel (1952, p. 32) to be equivalent to the Neshoba Sand Member of the Tallahatta Formation. Various aspects of the geology of the Queen City Sand Member have been discussed by Smith (1958). The Queen City Sand Member is an important aquifer in northeastern Texas.

The Weches Greensand Member of the Mount Selman Formation overlies the Queen City Sand Member and consists predominantly of dark-green beds of glauconitic highly crossbedded, lenticular sand and of some thin strata of dark-gray to black glauconitic clay and shale. Limonite and siderite are concentrated sufficiently in places to make the unit of economic importance. The Weches Greensand Member is relatively thin; the unit probably is not more than 60 feet thick. It is equivalent to the Winona Sand and probably to Zilpha Clay of Mississippi.

Cane Rixer Formation.-The Cane River Formation (Spooner, 1926, p. 235-236) in Arkansas and Louisiana includes from 150 to more than 500 feet of clay, sandy clay, marl, and thin beds of fine sand. Marine clay is predominant, and the beds are, in part, glauconitic and calcareous. The Cane River Formation includes all 


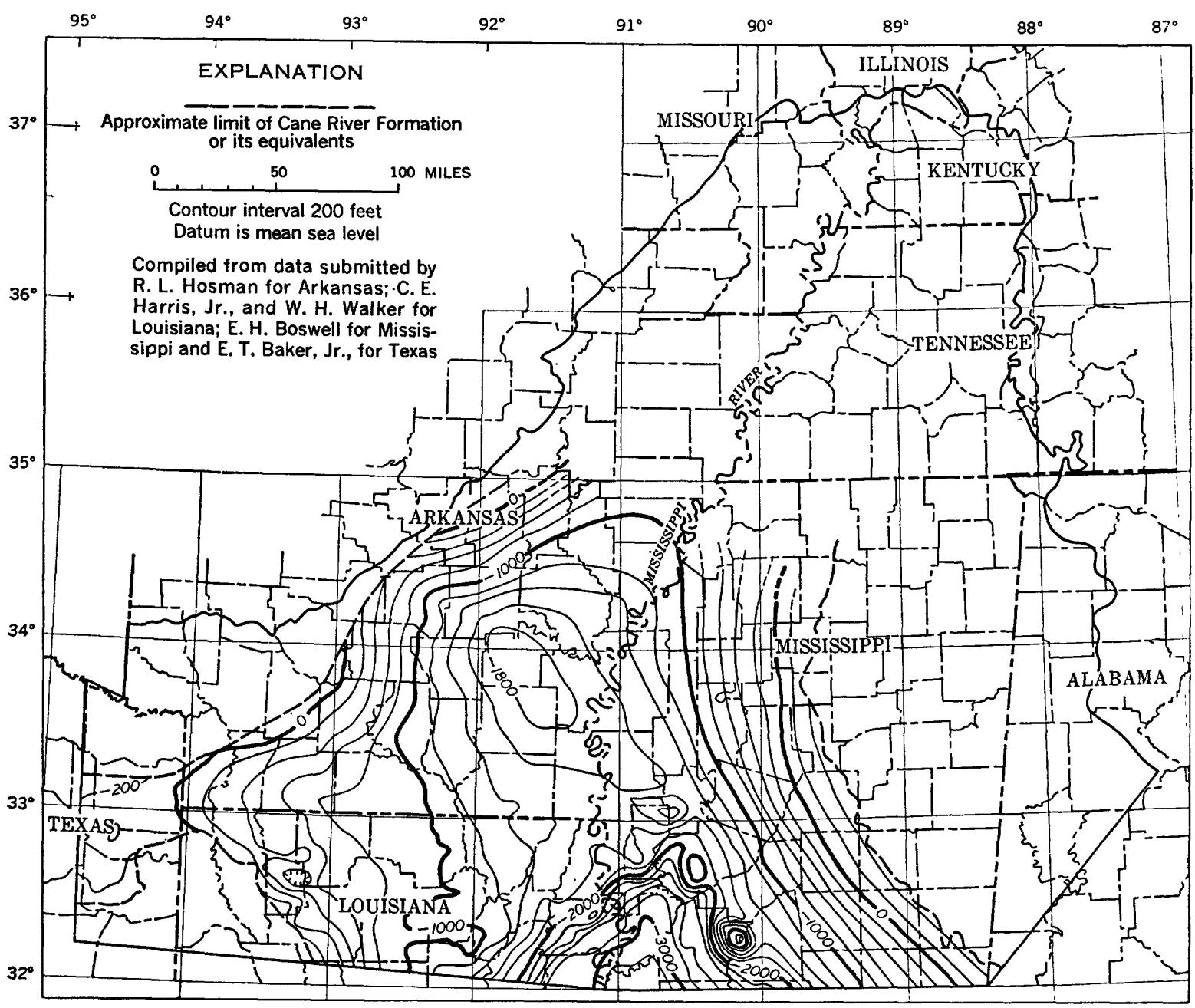

FIGURE 7.-Contour map showing configuration of the base of the Cane River Formation or its equivalents.

beds above the top of the Carrizo Sand and below the base of the Sparta Sand. It is correlative with the Mount Selman Formation and with the Tallahatta Formation (except the Meridian Sand Member), Winona Sand, and Zilpha Clay.

Figure 7 is a contour map showing configuration of the base of the Cane River Formation, the base of the Mount Selman Formation, and the base of the Basic City Shale Member of the Tallahatta Formation. The map is compiled for the southern part of the embayment, where these formations have been recognized.

The sands of the Cane River Formation are fine and relatively impermeable. In some areas these sands are important as aquifers.

Winona Sand.-In typical outcrops the Winona Sand (Lowe, 1919, p. 73) is a highly glauconitic fossiliferous sand and clay. It has been mapped only in Mississippi. In Tennessee and northward, the nonmarine sands equivalent to the Winona Sand are included in the undifferentiated Claiborne Group.
The Winona Sand ranges in thickness from less than 10 feet near the Alabama State line to a maximum of about 50 feet in north-central Mississippi, where it is locally an aquifer.

Zilpha Clay.-The Zilpha Clay (Thomas, 1942, p. 34) crops out in Mississippi but has not been recognized in other parts of the region. The top of the Zilpha Clay is equivalent to the top of the Cane River Formation of Arkansas and Louisiana and to the top of the Mount Selman Formation of Texas.

The thickness of the outcropping Zilpha Clay ranges from a few feet to 75 feet (Thomas, 1942, p. 38). It is much thicker in the subsurface to the southwest. The Zilpha is a dark-gray clay that is carbonaceous, generally glauconitic, sparingly fossiliferous, and predominantly of marine origin. It is not an aquifer.

Sparta Sand.-The Sparta Sand (originally defined by Vaughan, 1895, p. 225; restricted by Spooner, 1926, p. 235) crops out in Texas, Louisiana, Arkansas, and Mississippi. The Sparta has an average thickness in 


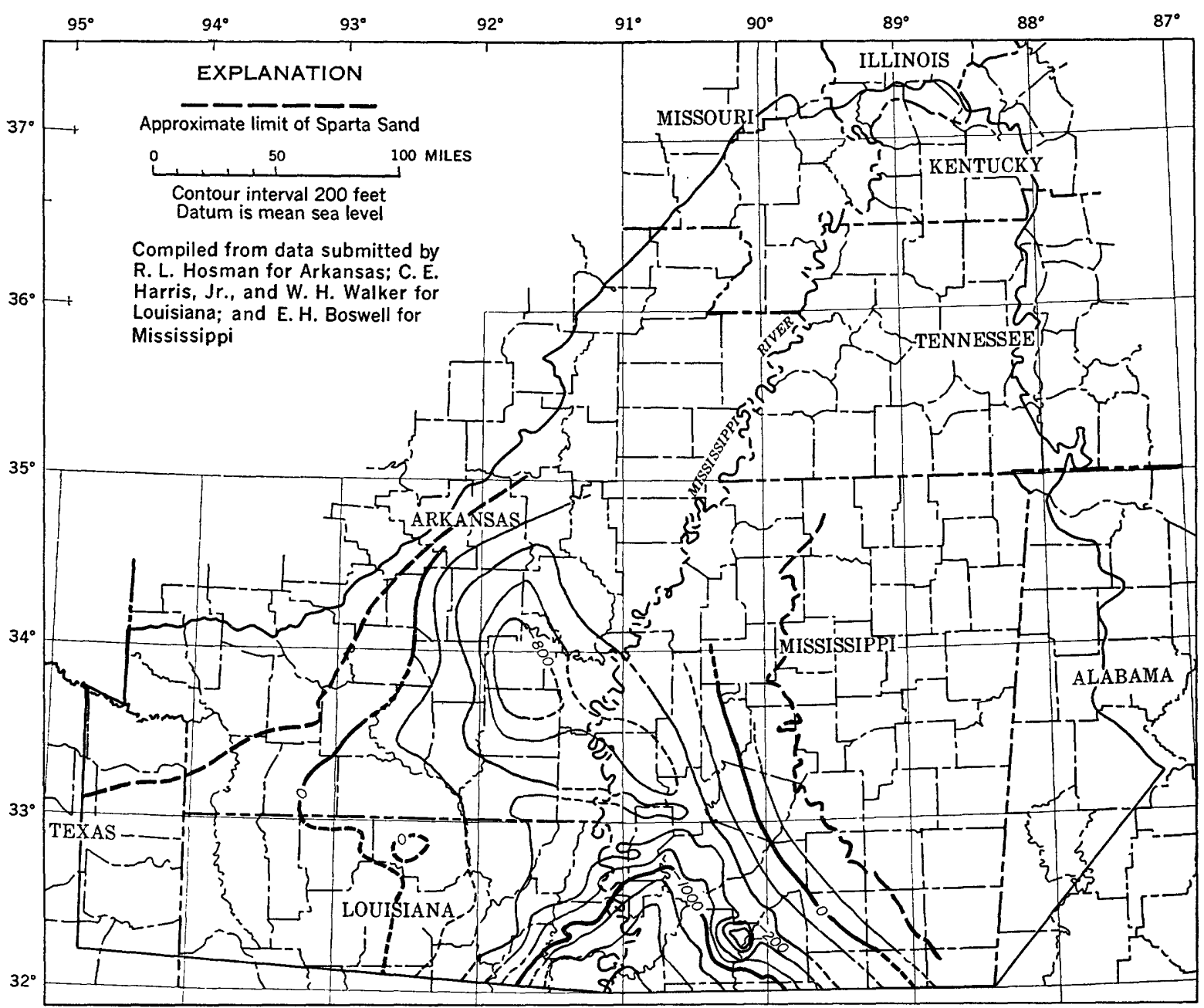

Figure 8.-Contour map showing configuration of the top of the Sparta Sand.

outcrops of about 300 feet, but it thins to less than 100 feet in southeastern Mississippi. It thickens considerably in the subsurface and may be as much as 1,000 feet thick near the axis of the embayment at the southern limit of the region. The upper part of the "500foot" sand of the Memphis area probably is Sparta Sand.

Figure 8 is a contour map showing configuration of the top of the Sparta Sand. It is compiled for the southern part of the region, where the sand has been recognized.

The Sparta is predominantly fluviatile sand containing subordinate amounts of sandy clay or shale. In Mississippi, the outcropping beds locally include ledges of orthoquartzite in the lower part of the unit, whereas in the upper part the sand is interbedded with light-gray clay. In the subsurface, lignite and other organic material are common. The Sparta Sand in Texas contains ferruginous sandstone ledges in some places.

The Sparta Sand is one of the most productive aquifers in the region.
Cook Mountain Formation.-The Cook Mountain Formation (Kennedy, 1892, p. 54-57) crops out in Mississippi, Arkansas, and Louisiana. The formation is about 100 feet thick in the outcrop area, and it has a maximum thickness of about 200 feet in the embayment.

In eastern Mississippi, the Cook Mountain Formation was divided by Thomas (1942, p. 49) into the Archusa Marl Member at the base, the Potterchitto Sand Member, and the Gordon Creek Shale Member. These units have not been identified in the subsurface, where the formation is generally divisible into only two lithologic units. In Mississippi, Arkansas, and Louisiana the lower part of the Cook Mountain is glauconitic, calcareous fossiliferous sandy marl or limestone and seems to be equivalent to the Archusa Marl Member. The upper unit is sandy carbonaceous clay or shale, which is locally glauconitic.

The Cook Mountain Formation is not important regionally as a source of water. 
Cockfield Formation.-The Cockfield Formation (Vaughan, 1895, p. 220) crops out in Arkansas, Louisiana, and Mississippi. It has an average thickness in outcrop of about 250 feet in Mississippi and thickens in the subsurface to a maximum of about 600 feet.

The Cockfield Formation is fine to medium quartz sand and carbonaceous clay. The formation is very lenticular, but sand is fairly persistent in the lower part. Lignite is common in the subsurface.

The Cockfield Formation is the youngest Eocene artesian aquifer in the Mississippi embayment.

\section{Jackson Group}

The Jackson (Conrad, 1856, p. 257-258) crops out in Louisiana, Arkansas, Tennessee, and Mississippi. The Jackson Group is undifferentiated in Arkansas and northern Mississippi, but in Louisiana and central Mississippi it is separated into the Moodys Branch Formation and Yazoo Clay. The Jackson is a formation in Tennessee.

The truncated Jackson Group underlies extensive deposits of the Mississippi River alluvium in the southern part of the region. The occurrence of a fossil bone of Jackson age in the bluffs along the Mississippi River about 35 miles north of Memphis indicates that the Jackson sea probably extended considerably farther northward. Some of the clays and silts in Kentucky may represent deposition in the northern extension of the sea. The Jackson sea was the last extensive marine invasion of the Mississippi embayment.

The Jackson Group does not include an aquifer in the region.

Moodys Branch Formation. - The Moodys Branch Formation (originally defined by Meyer, 1885, p. 435; described by Lowe, 1915, p. 75) is recognized in Mississippi and Louisiana. Normally 20 to 30 feet thick, it is a highly fossiliferous glauconitic sandy marl which unconformably overlies the uppermost beds of the Claiborne Group.

Yazoo Clay.-The Yazoo Clay (Lowe, 1915, p. 79) is calcareous fossiliferous dark-gray to blue clay. Its thickness ranges from 350 to 500 feet where the entire unit is present. The Yazoo Clay in Mississippi was divided, in ascending order, by Murray (1947, p. 1839) into the North Creek, Cocoa Sand, Pachuta Marl, and Shubuta Members. The contact of the Shubuta Member with the overlying Forest Hill Sand is the Eocene-Oligocene boundary.

\section{OLIGOCENE SERIES}

The Oligocene Series comprises the Forest Hill Sand (Cooke, 1918, p. 187) and the Vicksburg Group (Conrad, 1848 , p. 280-281). These units crop out in the extreme south-central part of the region and have an aggregate thickness averaging about 200 feet. They thicken in the subsurface.

The Forest Hill Sand is an aquifer of local importance. MIOCENE SERIES

The Catahoula Sandstone of Miocene age crops out in southern Hinds, Rankin, and Warren Counties, Miss. It was not studied in this investigation.

\section{QUATERNARY SYSTEM}

Deposits of Quaternary age cover much of the Coastal Plain surface and are assigned to the Pleistocene and Recent Epochs. The Quaternary sediments include sand, gravel, and clay occurring mostly as alluvial and terrace deposits. Loess covers much of the area east of the Mississippi River alluvial plain and caps Crowleys Ridge.

The sand and gravel deposits of the Mississippi River alluvial plain form the most important Quaternary ground-water reservoir. The thickness of the alluvium varies greatly, but generally ranges from 100 to 200 feet. The lower part generally is composed of gravel and very coarse sand, whereas the upper part typically includes fine to medium sand and clay. Many large-capacity wells obtain water from the Mississippi River alluvium.

Alluvial deposits along other streams have been extensively developed in localities where they are capable of yielding large quantities of water.

\section{STRUCTURE}

The present Mississippi embayment is a syncline plunging to the south. The axis of the syncline roughly follows the present course of the Mississippi River. The trough is filled with sedimentary rocks ranging in age from Jurassic to Recent and has been extensively modified by various structural features (fig. 9). The character of the deposits was controlled by a depositional environment resulting, in part, from the structure.

Initial tectonic movements that resulted in the formation of the Mississippi embayment syncline may have been a part of the Appalachin revolution at the end of the Paleozoic Era. The uplift of the Appalachian Mountains was accompanied by other subcrustal movement, and the initial subsidence in the southwestern part of the embayment may have occurred at this time.

The major portion of the syncline was not yet in existence at the end of the Paleozoic Era. At the beginning of the Mesozoic Era the eastern part of the Ouachita Mountain system, the Ozark uplift, and the southwestern extremity of the Appalachian Mountain system occupied part of the region. Since the Triassic Period, weathering of these uplifted areas has produced 


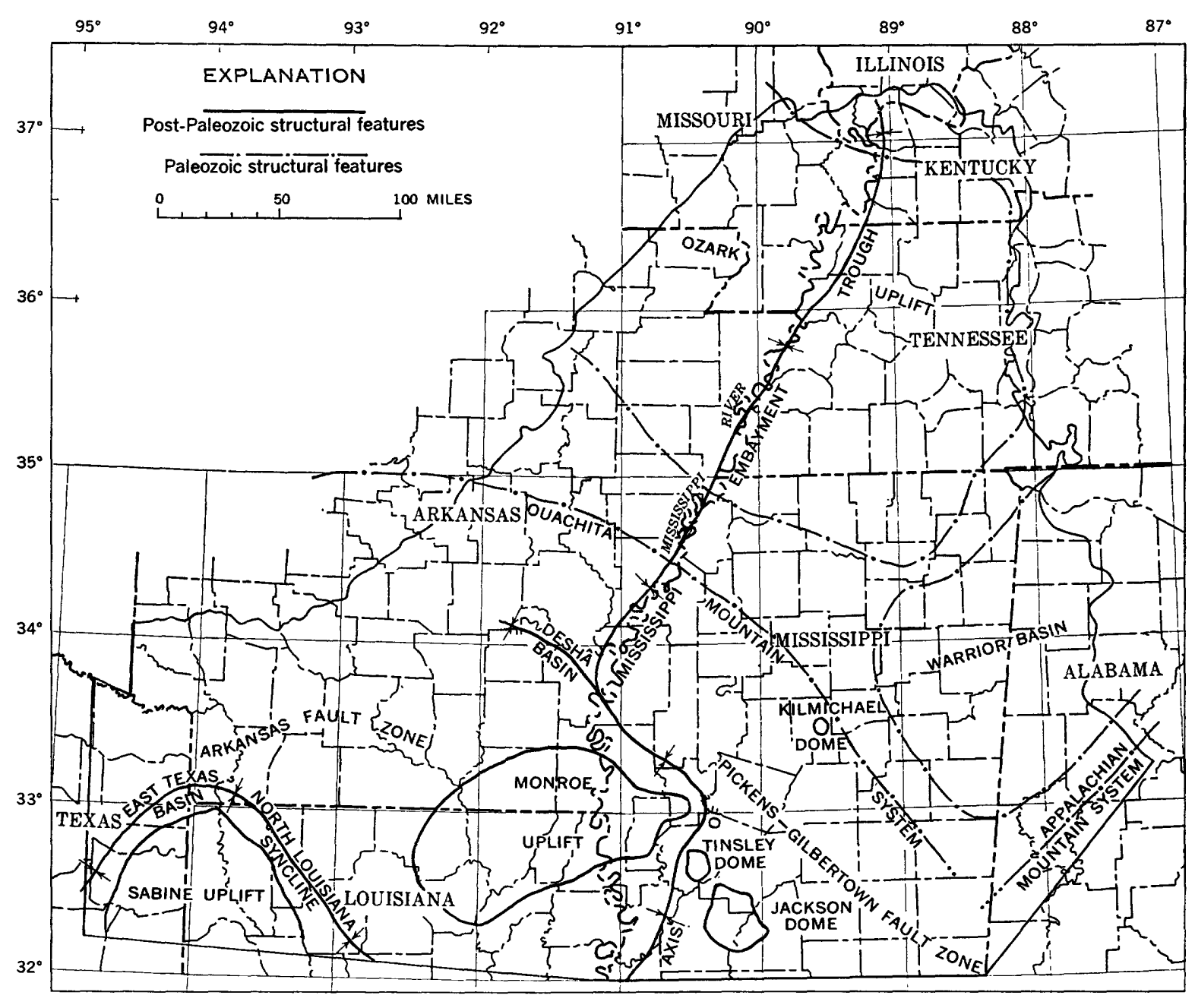

Figure 9,-Structure map of the Mississippi embayment.

vast quantities of detrital material which was transported and deposited to form part of the complex sedimentary-rock assemblage in the present embayment. The sedimentation occurred concurrently with subsidence and inundation of the Gulf Coast geosyncline and the trough of the Mississippi embayment. The subsidence is presumed to have been caused primarily by subcrustal movement and sedimentary loading and also by compaction of the sediments.

Many of the rock units in the Mississippi embayment change from a clastic facies in the northern part of the region near the source of the sedimentary material, through an intermediate facies characteristic of continental shelves, to deeper marine deposits in the southern part of the embayment or in the Gulf Coast geosyncline. Most types of sedimentary rocks are represented in the region. The units thicken gradually downdip and abruptly through zones of increased subsidence. The maximum thickness of post-Paleozoic sediments, about 18,000 feet, occurs at the axis of the embayment in the extreme southern part of the region.

\section{MESOZOIC ERA}

TRIASSIC PERIOD

No direct evidence of a sedimentary basin during the Triassic Period has been observed. Any sediments of Triassic age were eroded or have not been identified.

\section{JURASGIC PERIOD}

During the Jurassic Period the southern part of the Mississippi embayment was a sedimentary basin, and deposits of Late Jurassic age occur in the subsurface. The northern limit of these sediments is near the southern flank of the buried eastern extension of the Ouachita Mountain system, a fact which indicates that the system was still positive enough to have considerable control on deposition. The character of the Jurassic sediments indicates that a large river in northern Mississippi was the source of material in the ArkansasMississippi area (Imlay, 1943, p. 1451, 1524). The areal configuration and thickness of the deposits indicate that the axis of the embayment was slightly east of the present trough. Also, the Sabine uplift area was a basin 
and a center of Late Jurassic deposition (Imlay, 1956; pl. 8).

\section{CRetaceous period}

The fact that Lower Cretaceous rocks extend farther north (Nunnally and Fowler, 1954) than the underlying Jurassic deposits indicates that subsidence continued into Early Cretaceous time and that the boundary effect which the Ouachita Mountain system had on deposition decreased. In the extreme southern part of the embayment, a sufficient thickness of sediment had accumulated over the Jurassic sedimentary salt beds to start the intermittent upward movement of the salt plugs and folds which eventually formed salt domes; however, most of the upward movement seems to have occurred during the Tertiary Period.

During the Late Cretaceous Epoch, the sea reached its maximum northern limit for the Mesozoic Era. Upper Cretaceous sediments were deposited throughout the embayment, and subsidence and deposition continued at an accelerated though intermittent rate. Volcanic activity was common, as indicated by widespread volcanic material in Upper Cretaceous rocks. The Sabine uplift is of early Late Cretaceous age. Near the end of Late Cretaceous time the Monroe uplift created a structural high across the original axis of the embayment, partially isolating the Desha basin.

The Desha basin occupies the part of the original embayment trough north of the Monroe uplift. The Jackson dome resulted from an igneous intrusion near the end of the Late Cretaceous, although some movement continued to occur at least until Oligocene time. Several other smaller structural features of igneous or volcanic origin were formed, and the Mississippi embayment assumed its present size and shape by the end of the Cretaceous Period.

\section{CENOZOIC FRA}

\section{TERTLARY PERIOD}

The Tertiary Period is characterized by a series of cyclic inundations and regressions by the sea. The maximum northern extent of inundation was probably during late Midway time. There is evidence that uplift of the Appalachian Mountains continued intermittently at least into the Eocene (Todd and Folk, 1957); this uplift was accompanied by subsidence in the embayment due to subcrustal movement, loading, and compaction. Widespread faulting is reflected, in part, by flexure zones along the edges of continental shelves. Axes of deposition for most of the Tertiary units are similar, and so are the configurations of the surfaces of the units as shown on the contour maps (figs. 6, 7, and 8). The last widespread inundation by the sea occurred during Jackson time at the end of the Eocene Epoch. The sea left evidence of its presence as far north as Tennessee and may have extended considerably farther north. Since the end of Jackson time, most of the Mississippi embayment has remained above sea level.

\section{QUATHRNARY PERIOD}

General subsidence and adjustment continued during the Quaternary Period. The initial uplift of the Kilmichael dome may have occurred as early as late Eocene, but the structure may be of Quaternary age. The alluvial fill of the Mississippi River valley was deposited and extensive terrace systems were formed during the Quaternary. Some diastrophism has occurred during historic time; the formation of Reelfoot Lake, for example, was the result of faulting associated with the New Madrid earthquakes of 1811-12.

\section{PHYSIOGRAPHY}

The Mississippi embayment is a part of the Atlantic Coastal Plain (Fenneman, 1938, p. 1) and lies within the Gulf Coastal Plain. The syncline forming the embayment is filled with sedimentary rocks, which crop out in a modified belted pattern (pl. 1). Differential erosion of these rocks has resulted in several physiographic districts typical of the Coastal Plain province. The embayment is separable into two general physiographic areas, the lowland of the Mississippi Alluvial Plain and the Coastal Plain uplands. Figure 10 shows the more important physiographic districts of the region.

The physiographic districts on the eastern side of the embayment are the Fall Line Hills, Black Belt, Pontotoc Ridge and Ripley Cuesta, Flatwoods, North Central Plateau, Buhrstone Cuesta, Jackson Prairie, Southern Pine Hills, and Loess Hills.

The Fall Line Hills occupy the periphery of the embayment from Alabama to southern Tennessee and constitute an area of rugged topography formed from the outcropping resistant sands of the Tuscaloosa Group, the McShan and Eutaw Formations, and the Coffee Sand. The district becomes indistinct in southern Tennessee, as the result of successive pinch out of progressively younger underlying geologic units.

The Black Belt is the topographic expression of the carbonate units of the Selma Group. The district is characterized by gently rolling to nearly flat terrain and reaches its maximum width in western Alabama and central Mississippi. The district narrows abruptly in northern Mississippi and becomes indistinct in southern Tennessee.

The Ripley, Owl Creek, and Clayton Formations underlie the Pontotoc Ridge in northern Mississippi and southern Tennessee, and the Ripley Formation, Prairie Bluff Chalk, and Clayton Formation underlie the Ripley Cuesta in western Alabama. Between these districts, the Ripley is similar in lithology to the underlying Demopolis Chalk and the outcrop area is 


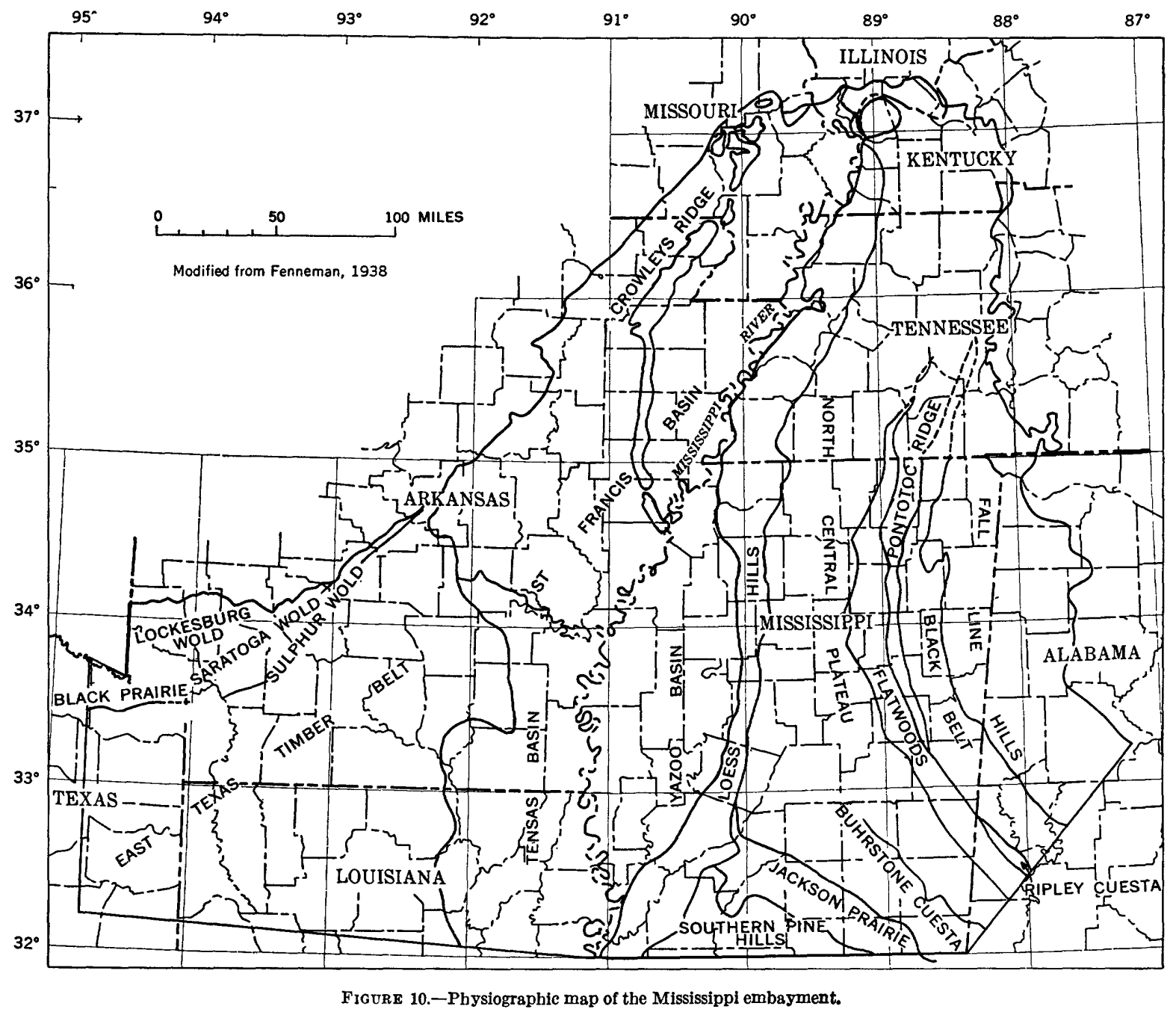

included in the Black Belt. Fenneman (1938, pl. 6) shows the Pontotoc Ridge extending a short distance into Tennessee. However, an extension of the ridge may form the divide between the Tennessee and Mississippi Rivers in northern Tennessee and Kentucky.

In western Alabama the Ripley Formation again becomes sandy, and the outcropping beds form the Ripley Cuesta. The relatively resistant limestone beds of the Clayton Formation are an important factor in the formation of the Pontotoc Ridge and the Ripley Cuesta.

The Flatwoods district is a level belt, as much as 10 miles wide, which extends from Alabama through Mississippi into southern Tennessee. The district is mostly forested, because the clay soils, derived from the underlying Porters Creek Clay, generally are not suitable for crops. The Porters Creek Clay thins northward, and as a result the Flatwoods belt narrows in northern Mississippi and becomes indistinct in southern Tennessee.
The gulfward margin of the Flatwoods is bordered by the North Central Plateau. This district is underlain by the dissected outcropping Wilcox and Claiborne deposits, which are predominantly sandy. The topography is modified by extensive terrace and loess deposits. In southeastern Mississippi and southwestern Alabama the North Central Plateau includes a line of hills referred to as the Buhrstone Cuesta (Tallahatta Hills). This cuesta, underlain by the Tallahatta Formation, which includes highly resistant sandstone interbedded with the characteristic claystone of the formation, forms one of the most rugged districts of the Coastal Plain.

The North Central Plateau is bordered on the south by the Jackson Prairie, underlain by the clays of the Jackson Group, and characterized by gently rolling topography. A small area south of the Jackson Prairie is in the Southern Pine Hills.

A distinctly different physiographic feature, the Loess Hills (Bluff Hills), forms the western border of 
the uplands of the East Gulf Coastal Plain of Fenneman (1938). The Loess Hills-superimposed on the North Central Plateau, the Jackson Prairie, and the Southern Pine Hills-are the result of the unique erosional characteristics of loess. The loess, when eroded, forms vertical walls which overlie the steep slopes scoured by the Mississippi River along the eastern side of the alluvial plain. The resulting scarp, extending from Mississippi to Kentucky, is one of the most notable physiographic features of the Coastal Plain.

The physiographic districts on the western side of the embayment are the Lockesburg Wold, Saratoga Wold, Sulphur Wold, Black Prairie, and East Texas Timber Belt.

Fenneman (1938, fig. 28) shows the physiographic divisions for northeastern Texas on a section of the West Gulf Coastal Plain near the course of the Trinity River. These divisions are based on the type of underlying rock. Fenneman $(1938$, p. 103) states that

the Grand Prairie covers all Lower Cretaceous rocks except the basal (Trinity) sands which underlie the narrow belt of Western Cross Timbers. The Black Prairie covers the Upper Cretaceous with a like exclusion of basal (Woodbine) sands bearing the Eastern Cross Timbers, while the East Texas Timber belt is on the Tertiary.

The Western Cross Timbers, the Grand Prairie, and the Eastern Cross Timbers narrow northeastward and converge in southwestern Arkansas to form the Lockesburg Wold of Veatch (1906, p. 15). Dane (1929, p. 28) indicates that the Lockesburg Wold, or cuesta, actually includes two cuestas. One is formed on the basal gravel of the Woodbine Formation and the other on the basal gravel of the Tokio Formation.

South of the Lockesburg Wold is the Saratoga Wold (cuesta) of Veatch (1906, p. 15). The Saratoga Wold is a topographic ridge underlain by the Nacatoch Sand.

Farther south is the Sulphur Wold of Veatch (1906, p. 15). It is a dissected topographic ridge underlain by sandy units of the Wilcox Group in Arkansas.

The Black Prairie of northeastern Texas is underlain by Upper Cretaceous rocks and is similar to the Black Belt of the East Gulf Coastal Plain. This district apparently terminates at the alluvial valley of the Red River in northeastern Texas. It has not been extended into Arkansas.

South of the Black Prairie belt is the East Texas Timber Belt, which is underlain by Tertiary units. It extends through northeastern Texas into northern Louisiana and southwestern Arkansas.

The Mississippi Alluvial Plain is the result of aggradation by the Mississippi River and its tributaries. During the last stages of the evolution of the Mississippi embayment, the Mississippi River cut a deep valley into the underlying rocks, mostly of Eocene age, at a time when the sea level was probably relatively much lower than it is at present. The general rise in sea level was accompanied by aggradation of the valley which, after a complex history (described in detail by Fisk, 1944) gradually assumed its present form. The alluvial plain is as much as 100 miles wide and about 400 miles long in the Mississippi embayment. It is flat and slopes almost imperceptibly gulfward. Various physiographic features, such as natural levees, oxbow lakes, abandoned meanders, and alluvial fans, occur in the plain. An outstanding feature is Crowleys Ridge, the remnant of an old divide extending from southeastern Missouri to east-central Arkansas (fig. 10).

The Mississippi Alluvial Plain is divided into several basins, three of which are within the Mississippi embayment. The St. Francis Basin extends from the apex of the embayment to the Arkansas River; the Yazoo Basin occupies the part of the alluvial plain east of the Mississippi River from Memphis, Tenn., to Vicksburg, Miss.; and the Tensas Basin is in the part of the alluvial plain west of the Mississippi River and south of the Arkansas River.

\section{SELEC'TED BIBLIOGRAPHY}

Adams, G. I., Butts, Charles, Stephenson, I. W., and Cooke, C. W., 1926, Geology of Alabama: Alabama Geol. Survey Spec. Rept. 14, 312 p.

Adkins, W. S., 1932, The Mesozoic systems in Texas in Sellards, E. H., Adkins, W. S., and Plummer, F. B., The geology of Texas, v. 1, Stratigraphy: Texas Univ. Bull. 3232, p. 239-518.

Alabama Geological Survey, 1926, Geological Map of Alabama: Prepared in cooperation with U.S. Geol. Survey.

Arkansas Geological Survey, 1929, Geologic Map of Arkansas.

Bornhauser, Max, 1947, Marine sedimentary cycles of Tertiary in Mississippi embayment and central Gulf Coast area: Am. Assoc. Petroleum Geologists Bull., v. 31, no. 4, p. 698-712.

1958, Gulf Coast tectonics: Am. Assoc. Petroleum Geologists Bull., v. 42, no. 2, p. 339-370.

Branner, J. C., 1898, The cement materials of southwest Arkansas: Am. Inst. Mining Engineers Trans., v. 27, p. 52-59.

Brown, G. F., 1947, Geology and artesian water of the alluvial plain in northwestern Mississippi: Mississippi Geol. Survey Bull. 65, 424 p.

Brown, G. F., and Adams, R. W., 1943, Geology and groundwater supply at Camp McCain [Mississippi]: Mississippi Geol. Survey Bull. 55, 116 p.

Caplan, W. M., 1954, Subsurface geology and related oil and gas possibilities of northeastern Arkansas: Arkansas Resourees and Devel. Comm., Div. Geology Bull. 20, 124 p.

Conant, L. C., 1941, Geology in Conant, L. C., and MeCutcheon, T. E., Tippah County mineral resources: Mississippi Geol. Survey Bull. 42 , p. 11-110.

1946, Vick Formation of pre-Tuscaloosa age of Alabama Coastal Plain: Am. Assoc. Petroleam Geologists Bull., v. 30, no. 5, p. 711-715. 
Conrad, T. A., 1848, Observations on the Eocene formation and description of 105 new fossils of that period, from the vicinity of Vicksburg, Miss.: Philadelphia Acad. Nat. Sci. Proc. 1847, 1st ser., v. 3, p. 280-299.

1856, Observations on the Eocene deposit of Jackson, Miss., with descriptions of 34 new species of shells and corals: Philadelphia Acad. Nat. Sci. Proc. 1855, 1st ser., v. 7 , p. 257-258.

Cooke, C. W., 1918, Correlation of the deposits of Vicksburg and Jackson ages in Mississippi and Alabama: Washington Acad. Sci. Jour., v. 8, p. 186-189.

Crider, A. F., and Johnson, L. C., 1906, Summary of the underground-water resources of Mississippi: U.S. Geol. Survey Water-Supply Paper 159, 86 p.

Dall, W. H., 1898, A table of North American Tertiary horizons correlated with one another and with those of western Europe, with annotations: U.S. Geol. Survey Ann. Rept. 18 , pt. 2, p. 323-348.

Dane, C. H., 1926, Oil-bearing formations of southwestern Arkansas: U.S. Geol. Survey Press Bull. 8823, 7 p.

- 1929, Upper Cretaceous formations of southwestern Arkansas: Arkansas Geol. Survey Bull. 1, 215 p.

Darton, N. H., and others, 1937, Geologic map of Texas: U.S. Geol. Survey.

Drennen, C. W., 1953a, Reclassification of the outcropping Tuscaloosa group in Alabama: Am. Assoc. Petroleum Geologists Bull., v. 37, no. 3, p. 522-538.

- 1953b, Stratigraphy and structure of outcropping pre-Selman Coastal Plain beds of Fayette and Lamar Counties, Alabama: U.S. Geol. Survey Circ. 267, 9 p.

Durham, C. O., Jr., and Smith, C. R., 1958, Louisiana MidwayWilcox correlation problems: Louisiana Dept. Conserv. Geol. Pamph. 5, 17 p.

Eardley, A. J., 1939, Paleotectonic and paleogeographic maps of central and western North America: Am. Assoc. Petroleum Geologists Bull., v. 33, no. 5, p. 655-682.

- 1951a, Tectonic divisions of North America: Am. Assoc. Petroleum Geologists Bull., v. 35, no. 10, p. 22292237.

- $1951 \mathrm{~b}$, Structural geology of North America: New York, Harper \& Bros., 624 p.

Eargle, D. H., 1946, Correlation of the pre-Selma Upper Cretaceous formations between Tuscaloosa County, Alabama, and Neshoba County, Mississippi: U.S. Geol. Survey Oil and Gas Inv. Prelim. Chart 20.

- 1948, Correlation of pre-Selma Upper Cretaceous rocks in northeastern Mississippi and northwestern Alabama: U.S. Geol. Survey Oil and Gas Inv. Prelim. Chart 35.

Eckel, E. B., 1938, The brown iron ores of eastern Texas: U.S. Geol. Survey Bull. 902, 157 p.

Ellisor, A. C., 1929, Correlation of the Claiborne of east Texas with the Claiborne of Louisiana: Am. Assoc. Petroleum Geologists Bull., v. 13, no. 10, p. 1335-1346.

Fenneman, N. M., 1938, Physiography of eastern United States: New York, McGraw-Hill Book Co., 714 p.

Fisk, H. N., 1944, Geological investigation of the alluvial valley of the lower Mississippi River: U.S. Dept. Army, Mississippi River Comm., 78 p.

Foster, V. M., 1940, Geology in Foster, V. M., and McCutcheon, T. E., Lauderdale County mineral resources: Mississippi Geol. Survey Bull. 41, p. 9-172.

Gardner, J. A., 1933a, The Midway group of Texas: Texas Univ. Bull. 3301,403 p.
- 1933b, Kincaid formation, name proposed for lower Midway of Texas: Am. Assoc. Petroleum Geologists Bull., v. 17 , no. 6 , p. $744-747$.

Geologic Map of Alabama, 1926: Alabama Geol. Survey in cooperation with the U.S. Geol. Survey.

Glenn, L. C., 1906, Underground waters of Tennessee and Kentucky west of Tennessee River and of an adjacent area in Jllinois: U.S. Geol. Survey Water-Supply Paper 164, $173 \mathrm{p}$.

Gordon, C. H., 1909, The chalk formations of northeast Texas: Am. Jour. Sci., 4th ser., v. 27, p. 369-373.

- 1911, Geology and underground waters of northeastern Texas: U.S. Geol. Survey Water-Supply Paper 276, 78 p.

Gordon, Mackenzie, Jr., Tracey, J. I., Jr., and Ellis, M. W., 1958, Geology of the Arkansas bauxite region: U.S. Geol. Survey Prof. Paper 299, 268 p.

Grim, R. E., 1936, The Eocene sediments of Mississippi: Mississippi Geol. Survey Bull. 30, 240 p.

Grohskopf, J. G., 1955, Subsurface geology of the Msisissippi embayment of southeast Missouri: Missouri Geol. Survey and Water Resources, 2d ser., v. 37, 133 p.

Heilprin, Angelo, 1882, Notes on the Tertiary geology of the southern United States: Philadelphia Acad. Nat. Sci. Proc. 1881, v. 33, p. 151-159.

Hilgard, E. W., 1860, Report on geology and agriculture of Mississippi: Jackson, Miss., State printer, 391 p.

1867, On the Tertiary formations of Mississippi and Alabama: Am. Jour. Sci., 2d ser., v. 43, p. 29-41.

Hill, R. T., 1887, The topography and geology of the Cross Timbers and surrounding regions in northern Texas: Am. Jour. Sci., 3d ser., v. 33, no. 196, p. 291-303.

1888, The Neozoic geology of southwestern Arkansas: Arkansas Geol. Survey Ann. Rept. for 1888, v. 2, 260 p.

- 1891, The Comanche series of the Texas-Arkansas region: Geol. Soc. America Bull., v. 2, p. 503-528.

1894, Geology of parts of Texas, Indian Territory, and Arkansas adjacent to Red River: Geol. Soc. America Bull., v. 5, p. $297-338$.

1901, Geography and geology of the Black and Grand Prairies, Texas, with detailed descriptions of the Cretaceous formations and special reference to artesian waters: U.S. Geol. Survey 21st Ann. Rept., pt. 7, 666 p.

Hughes, R. J., 1958, Kemper County Geology: Mississippi Geol. Survey Bull. 84, 274 p.

Imlay, R. W., 1943, Jurassic formations of the Gulf Region: Am. Assoc. Petroleum Geologists Bull., v. 27, no. 11, p. 14471553.

- 1944, Correlation of the Lower Cretaceous formations of the Coastal Plain of Texas, Louisiana, and Arkansas: U.S. Geol. Survey Oil and Gas Inv. Prelim. Chart 3.

1956, Paleogeography in McKee, E. D., and others, Paleotectonic maps, Jurassic system, with a separate section on paleogeography by R. W. Imlay: U.S. Geol. Survey Misc. Geologic Inv. Map I-175, 6 p.

Kennedy, W., 1892, A section from Terrell, Kaufman County, to Sabine Pass on the Gulf of Mexico: Texas Geol. Survey 3d Ann. Rept., p. 41-125.

King, P. B., 1950, Tectonic framework of southeastern United States: Am. Assoc Petroleum Geologists Bull., v. 34, no. 4, p. 635-671.

1959, The evolution of North America: Princeton, Princeton Univ. Press. 
Klaer, F. H., Jr., 1940, Memphis in Meinzer, O. E., Wenzel, L. K., and others, Water levels and artesian pressure in observation wells in the United States in 1940, pt. 2, Southeastern States: U.S. Geol. Survey Water-Supply Paper 907, p. 92-101.

LaMoreaux, P. E., and Toulmin, L. D., 1959, Geology and ground-water resources of Wilcox County, Alabama: Alabama Geol. Survey County Rept. 4, 280 p.

Langdon, D. W., 1891, Variation in the Cretaceous and Tertiary strata of Alabama: Geol. Soc. America Bull., v. 2, p. 587606.

Lowe, E. N., 1913, Preliminary report on iron ores of Mississippi: Mississippi Geol. Survey Bull. 10, 70 p.

1915, Mississippi, its geology, geography, soils and mineral resources: Mississippi Geol. Survey Bull. 12, 335 p.

1919, Mississippi, its geology, geography, soil and mineral resources: Mississippi Geol. Survey Bull. 14, $346 \mathrm{p}$.

1933, Coastal Plain stratigraphy of Mississippi, Midway and Wilcox groups: Mississippi Geol. Survey Bull. 25, pt. $1,125 \mathrm{p}$.

MacNeil, F. S., 1946, Summary of the Midway and Wilcox stratigraphy of Alabama and Mississippi: U.S. Geol. Survey Minerals Inv. Prelim. Rept. 3-195, 29 p.

- 1947, Correlation chart for the outcropping Tertiary formations of the eastern Gulf region: U.S. Geol. Survey Oil and Gas Inv. Prelim. Chart 29.

McGlothlin, Tom, 1944, General geology of Mississippi: Am. Assoc. Petroleum Geologists Bull., v. 28, no, 1, p. 29-62.

McKee, E. D., and others, 1956, Paleotectonic maps, Jurassic system, with a separate section on paleogeography by $R$. W. Imlay: U.S. Geol. Survey Misc. Geol. Inv. Map I-175, 6 p.

Mellen, F. F., 1958, Cretaceous shelf sediments of Mississippi: Mississippi Geol. Survey Bull. 85, 112 p.

1939, Geology in Mellen, F. F., and McCutcheon, T. E., Winston County mineral resources: Mississippi Geol. Survey Bull. 38, p. 15-90.

Meyer, Otto, 1885, The genealogy and the age of the species in the southern Old-Tertiary: Amer. Jour. Sci., 3d ser., v. 30, p. 421-425, 435.

Miser, H. D., and Purdue, A. H., 1918a, Gravel deposits of the Caddo Gap and DeQueen quadrangles, Arkansas: U.S. Geol. Survey Bull. 690-B, p. 15-30.

- 1918b, Geology of the DeQueen and Caddo Gap quadrangles, Arkansas: U.S. Geol. Survey Bull. 808, 195 p.

Mississippi Geological Society, 1945, Geologic map of Mississippi: Jackson, Miss., prepared in coop with U.S. Geol. Survey.

Missouri Geological Survey and Water Resources, 1961, Geologic map of Missouri.

Monroe, W. H., 1955, Cores of pre-Selma Cretaccous rocks in the outcrop area in western Alabama: Gulf Coast Assoc. Geol. Soc. Trans., v. 5, p. 11-38.

1956, Bluffport marl member of Demopolis chalk, Alabama: Am. Assoc. Petroleum Geologists Bull., v. 40, no. 11, p. 2740-2742.

Monroe, W. H., Conant, L. C., and Eargle, D. H., 19-16, PreSclma Upper Cretaccous stratigraphy of western Alabama: Am. Assoc. Petroleum Geologists Bull., v. 30, no. 2, p. 187-212.

Moody, C. L., 1931, Tertiary history of region of Sabine uplift, Louisiana: $\Lambda \mathrm{m}$. Assoc. P'etroleum Geologists Bull., v. 15, no. 5 , p. 541-551.

Murray, G. I., 19.17, Cenozoic deposits of central Gulf Coastal Plain: Am. Assoc. Petrolcum Grologists Bull., v. 31, no. 10 , p. 1835-1850.
1948, Geology of Red River and De Soto Parishes: Louisiana Dept. Conserv. Geol. Bull. 25, 312 p.

Murray, G. E., and Thomas, E. P., 1945, Midway-Wilcox surface stratigraphy of Sabine uplift, Louisiana and Texas: Am. Assoc. Petroleum Geologists Bull., v. 22, no. 1, p. 45-70.

Nunnally, J. D., and Fowler, H. F., 1954, Lower Cretaceous stratigraphy of Mississippi: Mississippi Geol. Survey Bull. $79,45 \mathrm{p}$.

Owen, John, 1889, Report of geologists for southern Texas: Texas Geol. Survey Prog. Rept. 1, p. 69-74.

Parks, W. S., 1960, Prentiss County geology: Mississippi Geol. Survey Bull. 87, $110 \mathrm{p}$.

Penrose, R. A. F., Jr., 1890, A preliminary report on the geology of the Gulf Tertiary of Texas from Red River to the Rio Grande: Texas Geol. Survey 1st Ann. Rept., p. 3-101.

Plummer, F. B., 1932, The Cenozoic systems in Texas in Sellards, E. H., Adkins, W. S., and Plummer, F. B., The geology of Texas, v. 1, Statigraphy: Texas Univ. Bull. 3232, p. 519-818.

Plummer, H. J., 1927, Foraminifera of the Midway formation in Texas: Texas Univ. Bull. 2644, 206 p.

Pryor, W. A., 1960, Cretaceous sedimentation in upper Mississippi embayment: Am. Assoc. Petroleum Geologists Bull., v. 44 , No. 9, p. 1473-1504.

Renfroe, C. A., 1949, Petroleum exploration in eastern Arkansas with selected well logs: Arkansas Resources and Devel. Comm., Div. Geology Bull. 14, 159 p.

Roberts, J. K., and Gildersleeve, Benjamin, 1945, Geology and mineral resources of the Jackson Purchase Region, Kientucky, with a section on Paleozoic geology by Louise Barton Freeman: Kentucky Geol. Survey, ser. 8, Bull. 8, 126 p.

Rollo, J. R.. 1960, Ground water in Louisiana: Louisiana Dept. Conserv., Geol. Survey, and Louisiana Dept. PublicWorks, $84 \mathrm{p}$.

Rouse, J. T., 1944, Correlation of Pecan Gap, Wolfe City, and Annona formations in east Texas: Am. Assoc. Petroleum Geologists Bull., v. 28, no. 4, p. 522-530.

Safford, J. M., 1864, On the Cretaceous and Superior formations of west Tennessee: Am. Jour, Sci., 2d ser., V. 37, p. 360-372.

1869, Geology of Tennessee: Nashville, Tenn., S. C. Mercer, printer to the State, $550 \mathrm{p}$.

Schneider, Robert, and Blankenship, R. R., 1950, Subsurface geologic cross section from Claybrook, Madison County. to Memphis, Shelby County, Tennessee: Tennessee Div. Geology Ground-Water Inv. Prelim. Chart 1.

Schneider, Robert, and Cushing, E. M., 1948, Geology and waterbearing properties of the " 1,400 -foot" sand in the Memphis area [Tennessee]: U.S. Geol. Survey Circ. 33, 13 p.

Schuchert, Charles, 1935, Ilistorical geology of the AntilleanCaribbean region: New York, John Wiley \& Sons, Inc., 811 p. - 19-43, Stratigraphy of the eastern and central United States: New York, John Wiley \& Sons, Inc., 1,013 p.

Shumard, B. F., 1861, Descriptions of new Cretaccous fossils from Texas: Boston Soc. Nat. Ilist. P'roc., v. 8, p. 188-205.

Smith, C. R., 1958, Queen City-Sparta relationships in Caddo Parish, Lonisiana: Am. Assoc. Petroleum Geologists IBull., v. 42 , no. 10 , p. $2517-2522$.

Smith, l. A., 1883, Report of progress for the years 1881 and 188: : Alabama Geol. Survey.

- 1886, Summary of the lithological and stratigraphic features and subdivisions of the Tertiary of Alabama in Aldrich, T. Il., Preliminary report on the Tertiary fossils of Alabama and Mississippi: Mlabama Geol. Survey liull. 1, p. 7-11. 
Smith, E. A., 1888, Geographic map of Alabama, in Alabama Geol. Survey Prog. Rept.

1903, The cement resources of Alabama: U.S. 58th Cong., 1st sess., S. Doc. 19, p. 12-20.

Smith, E. A., and Johnson, L. C., 1887, Tertiary and Cretaceous strata of the Tuscaloosa, Tombigbee, and Alabama Rivers: U.S. Geol. Survey Bull. 43, 189 p.

Smith, E. A., Johnson, L. C., and Langdon, D. W., Jr., 1894, Report on the geology of the Coastal Plain of Alabama, with contributions to its paleontology by T. H. Aldrich and K. M. Cunningham: Alabama Geol. Survey Spec. Rept. 6, 759 p.

Sohl, N. F., 1960, Archeogastropoda, Mesogastropoda and stratigraphy of the Ripley, Owl Creek, and Prairie Bluff Formations: U.S. Geol. Survey Prof. Paper 331-A, 151 p.

Spooner, W. C., 1926, Interior salt domes of Louisiana: Am. Assoc. Petroleum Geologists Bull., v. 10, no. 3, p. 217-292.

Stearns, R. G., 1958, Cretaceous, Paleocene, and Lower Eocene geologic history of the northern Mississippi embayment: Geol. Soc. America Bull., v. 68, p. 1077-1100.

Stearns, R. G., and Armstrong, C. A., 1955, Post-Paleozoic stratigraphy of western Tennessee and adjacent portions of the upper Mississippi embayment: Tennessee Div. Geology Rept. Inv. 2, 29 p.

Stenzel, H. B., 1952, Correlation chart of Eocene at outcrop in eastern Texas, Mississippi, and western Alabama: Mississippi Geol. Soc. Guidebook, 9th field trip, p. 32-33.

Stephenson, L. W., 1914, Cretaceous deposits of the eastern Gulf region and species of Exogyra from the eastern Gulf region and the Carolinas: U.S. Geol. Survey Prof. Paper 81, 77 p. - 1917, Tongue, a new stratigraphic term with illustrations from the Mississippi Cretaceous: Washington Acad. Sci. Jour., v. 7, p. 243-250.

- 1918, A contribution to the geology of northeastern Texas: U.S. Geol. Survey Prof. Paper 120-H, p. 129-163.

- 1927, Notes on the stratigraphy of the Upper Cretaceous formations of Texas and Arkansas: Am. Assoc. Petroleum Geologists Bull., v. 11, no. 1, p. 1-17.

1937, Stratigraphic relations of the Austin, Taylor, and equivalent formations in Texas: U.S. Geol. Survey Prof. Paper 186-G, p. 133-146.

1953, Probable Reklaw age of a ferruginous conglomerate in eastern Texas: U.S. Geol. Survey Prof. Paper 243-C, p. 31-43.

1955, Owl Creek (Upper Cretaceous) fossils from Crowleys Ridge, southeastern Missouri: U.S. Geol. Survey Prof. Paper 274-E.

Stephenson, L. W., and Crider, A. F., 1916, Geology and ground waters of northeastern Arkansas, with a discussion of the chemical character of the waters by R. B. Dole: U.S. Gcol. Survey Water-Supply Paper 399, 315 p.

Stephenson, L. W., King, P. B., Monroe, W. H., and Imlay, R. W., 1942, Correlation of the outcropping Cretaceous formations of the Atlantic and Gulf Coastal Plain and TransPecos Texas: Geol. Soc. America Bull., v. 53, p. 435-448.

Stephenson, L. W., Logan, W. N., and Waring, G. A., 1928, Ground-water resources of Mississippi, with discussions of the chemical character of the waters by C. S. Howard: U.S. Geol. Survey Water-Supply Paper 576, 515 p.

Stephenson, L. W., and Monroc, W. H., 1937, Prairie Bluff chalk and Owl Creek formation of eastern Gulf region: Am. Assoc. Petrolcum Geologists Bull., v. 21, no. 6, p. 806-809.
1938, Stratigraphy of Upper Cretaceous series in Mississippi and Alabama: Am. Assoc. Petroleum Geologists Bull., v. 22, no. 12, p. 1639-1657.

1940, The Upper Cretaceous deposits: Mississippi Geol. Survey Bull. 40, $296 \mathrm{p}$.

Storm, L. W., 1945, Resume of facts and opinions on sedimentation in Gulf Coast region of Texas and Louisiana: Am. Assoc. Petroleum Geologists Bull., v. 29, no. 9, p. 1304-1335.

Tennessee Division of Geology, 1933, Geologic map of Tennessee.

Thomas, E. P., 1942, The Claiborne: Mississippi Geol. Survey Bull. 48,96 p.

Todd, T. W., and Folk, R. I., 1957, Basal Claiborne of Texas, record of Appalachian tectonism during Eocene: Am. Assoc. Petroleum Geologists Bull., v. 41, no. 11, p. 25452566.

Toulmin, L. D., LaMoreaux, P. E., and Lanphere, C. R., 1951, Geology and ground-water resources of Choctaw County, Alabama: Alabama Geol. Survey Spec. Rept. 21, 197 p.

Tuomey, Michael, 1850, The geology of Alabama: Alabama Geol. Survey 1st Bienn. Rept., 196 p.

U.S. Geological Survey, 1932, Geologic map of the United States.

Vanderpool, H. C., 1928, A preliminary study of the Trinity group in southwestern Arkansas, southeastern Oklahoma, and northern Texas: Am. Assoc. Petroleum Geologists Bull., v. 12, no. 11, p. 1069-1094.

Vaughan, T. W., 1895, The stratigraphy of northwestern Louisiana: Am. Geologist, v. 15, p. 205-229.

Veatch, A. C., 1905, Louisiana and southern Arkansas in Fuller, M. L., Underground waters of eastern United States: U.S. Geol. Survey Water-Supply Paper 114, p. 179-187. - 1906, Geology and underground water resources of northern Louisiana and southern Arkansas: U.S. Geol. Survey Prof. Paper 46, 422 p.

Wade, Bruce, 1917, A remarkable Upper Cretaceous fauna from Tennessee: Johns Hopkins Univ. Circ., Contrib. to Geology, p. 73-101.

- 1926, The fauna of the Ripley formation on Coon Creek, Tennessee: U.S. Geol. Survey Prof. Paper 137, 272 p.

Waters, J. A., McFarland, P. W., and Lea, J. W., 1955, Geologic framework of Gulf Coastal Plain of Texas: Am. Assoc. Petroleum Geologists Bull., v. 39, no. 9, p. 1821-1850.

Wells, F. G., 1933, Ground-water resources of western Tennessee: U.S. Geol. Survey Water-Supply Paper 656, 319 p.

Wendlandt, E. A. and Knebel, G. M., 1929, Lower Claiborne of east Texas, with special reference to Mount Sylvan dome and salt movements: Am. Assoc. Petroleum Geologists Bull., v. 13, no. 10, p. 1347-1375.

Wilbert, L. J., Jr., 1953, The Jacksonian stage in southeastern Arkansas: Arkansas Resources and Devel. Comm., Div. Geology Bull. 19, 125 p.

Williams, N. F., and Plummer, Norman, 1951, Clay resources of the Wilcox group in Arkansas: Arkansas Resources and Devel. Comm., Div. Geology Inf. Circ. 15, 98 p.

Wilmarth, M. G., 1957, Lexicon of geologic names of the United States (including Alaska): U.S. Geol. Survey Bull. 896, $2396 \mathrm{p}$.

Wilson, Druid, Sando, W. J., and Kopf, R. W., 1957, Geologic names of North America introduced in 1936-1955: U.S. Geol. Survey Bull, 1056-A, 405 p.

Winchell, Alexander, 1857, Notes on the geology of middle and southern Alabama: Am. Assoc. Adv. Sci. Proc., v. 10, pt. 2, p. 82-93. 